\title{
Factors Affecting Family Business Succession in The Food Hawking Business in Malaysia
}

\author{
Jonathan Ng Cho Kin
}

Faculty of Business and Information Science, UCSI University

Correspondence:

Jonathan $\mathrm{Ng}$ Cho Kin

1001541681@student.ucsiuniversity.edu.my

jonathannck@hotmail.com

ORCID: 0000-0001-7681-8229 


\begin{abstract}
Food hawking businesses around the world largely contribute to the economy of countries and provides much needed jobs that feed employment, even though earnings are low. The food hawking business in Malaysia is under threat of extinction due to the reluctance of the next generation in taking over the food hawking businesses from the elderships. As research in the area of family business succession is scarce, this study serves to add to the theoretical aspect of the area. The purpose of this study was to analyse the effects of vending environment, operating hours, successor willingness, relationship among family members and preparation level of heir on the intention of family succession in the food hawking business in Malaysia. Leader's approval was also studied as a potential moderator. The methodology used was a questionnaire survey study design with a sample size of 208, respondents were obtained via convenience sampling from Kuala Lumpur and Penang as hawkers are abundant in these two locations. Findings show that vending environment, successor willingness, relationship among family members and preparation level of heir have a significant effect on the intention of family succession in the food hawking business in Malaysia. Leader's approval was found to be insignificant as a moderator. Operating hours was not significant, possibly due to the difference in importance placed by Malaysian hawkers in succession.
\end{abstract}

Keywords: family business, business succession, business performance, business planning, hawker business 


\section{INTRODUCTION}

\subsection{RESEARCH BACKGROUND}

Penang has been cited as the world's best street food destination and that only in Penang can one get good tasting food at such a cheap price (New Straits Time, 2016; Time Magazine, 2004). The travel guide book publisher "Lonely Planet" has stated in an article that George Town, Penang is the best street food city in Southeast Asia, food is cheap and delicious (Bush, 2015). The World Health Organization defines "street food" as food and beverages that are prepared and sold by vendors located in streets or public areas, for immediate consumption (Essential safety requirements for street-vended foods, 1996). Penang's tourism sector and economy also benefit from the food hawking industry. Food and tourism are linked, as food consumption is necessary for tourists and is highly profitable (Henderson et al., 2012).

Recently, food awareness in the tourism industry has escalated globally (Henderson et al., 2012). A survey on Penang tourism in 2016 showed that $46.3 \%$ of tourists said 'trying local cuisine' is the number one thing on their to-do list (Chong, 2019). 2017 was record breaking for Penang tourism, the total passenger traffic at Penang International Airport saw an increase of 7.98\% compared to 2016 (Tan, 2017).

The hawking conditions and earnings might be poor (Muzaffar, Huq \& Mallik, 2009), but food hawking in has contributed jobs (Kok, 2018; Iyenda, 2001) as well as food for the less fortunate (Ruel, Haddad \& Garrett, 1999; Henderson et al., 2012). Studies have found hawker businesses as a strategy to reduce poverty and promote entrepreneurship, especially in women (Henderson et al., 2012). Food hawking has shown to be essential in Malaysian tourism and the local economy. This research will be conducted to investigate the factors affecting family business succession in the food hawking business in Malaysia. 


\subsection{PROBLEM STATEMENT}

Despite the importance of street food in the tourism sector and economy of Malaysia, food hawkers in Malaysia are in danger of extinction. Hawkers in Singapore are facing a similar fate where the number of licensed street hawkers has decreased from 846 hawkers in 2010 to 561 hawkers in 2016 (Department of Statistics, Ministry of Trade and Industry, Republic of Singapore, 2017). Research has indicated that only $21 \%$ of total interviewed sample of Penang hawkers have a succession plan (Chong, 2019). The reluctance of the younger generation or children of these hawkers to carry on the street food business as a career is a major factor (Henderson et al., 2012; Chong,2019). If not addressed, street food in Malaysia may not survive and will negatively affect the economy of Malaysia. From a knowledge standpoint, although studies on family business succession have been done, many family businesses still fail before succession (Lucky, Minai \& Isaiah, 2011).

Many sources have reported that the vending environment (Kei, 2015; Kok, 2018; Kuratko \& Hodgetts, 2004; Westhead, 2003), operating hours (Kei, 2015; Kok, 2018; Chong, 2019), preparation level of heir (Lam, 2007; Castillo, 2006; Lorna, 2010; Sardeshmukh \& Corbett, 2011; Mokhber et al., 2017), relationship among family members (Castillo, 2006; Lorna, 2010; Mokhber et al., 2017; Kaunda \& Nkhoma, 2013; Helin \& Jabri, 2016), and successor willingness (Tarulevicz, 2018; Wang, Lo \& Weng, 2019) may have an effect on the succession of family businesses. These variables may be the key to understanding and solving the research problems of family hawker business succession in Malaysia. The potential moderation effect of the leader's or eldership's approval has also been tested in previous research by Wang, Lo \& Weng (2019). It is noteworthy however, that most studies in the field of family business succession were performed in a non-food, non-hawker setting. As such, it is important to study the effects of the variables from these studies in the family hawker business setting of Malaysia. 


\subsection{RESEARCH QUESTIONS}

I. Does vending environment affect family succession in the food hawking business of Malaysia?

II. Do the operating hours affect family succession in the food hawking business of Malaysia?

III. Does preparation level of heir affect family succession in the food hawking business of Malaysia?

IV. Does relationship among family members affect family succession in the food hawking business of Malaysia?

V. Does successor willingness affect family succession in the food hawking business of Malaysia?

VI. Does leader approval affect the relationship between vending environment and family succession in the food hawking business of Malaysia?

VII. Does leader approval affect the relationship between operating hours and family succession in the food hawking business of Malaysia?

VIII. Does leader approval affect the relationship between preparation level of heir and family succession in the food hawking business of Malaysia?

IX. Does leader approval affect the relationship between relationship among family members and family succession in the food hawking business of Malaysia?

X. Does leader approval affect the relationship between successor willingness and family succession in the food hawking business of Malaysia? 


\subsection{RESEARCH OBJECTIVES}

I. To investigate the relationship between vending environment and family succession in the food hawking business of Malaysia.

II. To investigate the relationship between the operating hours and family succession in the food hawking business of Malaysia.

III. To investigate the relationship between preparation level of heir and family succession in the food hawking business of Malaysia.

IV. To investigate the relationship between the relationship among family members and family succession in the food hawking business of Malaysia.

V. To investigate the relationship between successor willingness and family succession in the food hawking business of Malaysia.

VI. To investigate the moderation of the relationship between vending environment and family succession in the food hawking business of Malaysia in the presence of leader approval.

VII. To investigate the moderation of the relationship between operating hours and family succession in the food hawking business of Malaysia in the presence of leader approval.

VIII. To investigate the moderation of the relationship between preparation level of heir and family succession in the food hawking business of Malaysia in the presence of leader approval.

IX. To investigate the moderation of the relationship between relationship among family members and family succession in the food hawking business of Malaysia in the presence of leader approval. 
$X$. To investigate the moderation of the relationship between successor willingness and family succession in the food hawking business of Malaysia in the presence of leader approval.

\subsection{SIGNIFICANCE OF STUDY}

The food hawking business of Penang contributes greatly to the tourism sector and economy of Penang and thus Malaysia. Despite this, the street food businesses in Penang is on its last legs as majority of hawkers do not have a succession plan (Chong, 2019). Suggestions have been made for an in-depth study to determine the future supply of food hawkers, this will ensure food hawking sustainability (Chong, 2019). The perception of the food hawking business must also be made attractive for the younger generation to pursue as a career. On the contrary, research on succession and the factors affecting family business succession are scarce (Lucky, Minai and Isaiah, 2011). Research on family businesses are also slow going, this makes it necessary to increase our understanding in the area of family business (Heck et al., 2008). This study will improve the limited number of family business research and will help to identify factors affecting family business succession and further understand the relationship of the variables chosen. This study will also help the endangered food hawking businesses in Malaysia, for a more sustainable business and economy. This study will also encourage the younger people in pursuing their family owned food hawking business. Studies in the area of family business succession are limited and family business failure are apparent in the succession stage, despite availability of existing research. This study will help identify factors affecting family business succession, as it is of great importance to systematically identify the reasons that contribute to the survival of successful family firms across generations (Basco, Calabrò \& Campopiano, 2018). Tarulevicz (2018) has highlighted the growing concern of family hawker business succession and postulates that if studies on the topic continue to be scarce, so will the hawkers of today. Au (2018) mentions that research trends in family businesses have increased in the past years as researchers and business practitioners realize the importance. From a theory perspective, this study can provide academic insight into the problems faced by family hawker businesses during succession and can help to increase comprehension and expansion on family business 
research theory. By doing so, an evidence-based approach backed by academic research can be confidently applied to solve practical family business issues. 


\section{LITERATURE REVIEW}

\subsection{REVIEW ON INDEPENDENT VARIABLES AND DEPENDENT VARIABLES}

\subsubsection{Linkage of literature review to the problem statement}

In recent years, there has been increasing attention in the area of family business succession from academicians. Family business research is said to be shifting into the main stream with a growing number of papers appearing in leading journals; many journals have published special devoted issues on family business research (Au, 2018). This section will provide a brief overview of the current state of family business research.

Starting with earlier research studies on family business succession, a critical review was carried out on the early available literature. Collins (2010) studied the implications for family owned business successions. The study stated that individual, organization and family affected family business succession; issues surrounding research methodology was also analysed. Miller, Steier \& Le Breton-Miller (2003) performed research on the failure of family business in relationship to succession. The study stated that succession strategy, government, organisation and culture played important roles in succession. Lam (2009) concluded that founder and successor are major factors that would affect family business succession. However, this study did not explore the other factors outside of the family that other studies had explored. Lucky, Minai \& Isaiah (2011) mentioned that relationship management, team work, leadership and successor preparation would affect succession in family business. Kuratko \& Hodgetts (2004) stated that environment, internal factors and external factors affect family business succession, however, the study inconsistent on what internal and external factors are. Westhead (2003) explored internal and external environment, concluding that external environment would affect the family business succession. Sardeshmukh \& Corbett (2011) studied on how preparation of successors would lead to opportunity recognition in family owned 
businesses and lead to succession, the study concluded that successor preparation is significant.

Critically reviewing the available contemporary studies on family business succession has also yielded results that indicate an increase in academic interest compared to earlier times. The area is actively researched by the Successful Transgenerational Entrepreneurship Practices (STEP) Project. STEP is a global applied research initiative and collaborative effort by participating scholars whose objective is to perform research into the successful entrepreneurial practices of family businesses over time. STEP performs both qualitative and quantitative research. STEP researches aim to disseminate evidence-based knowledge through publications and summits with families (Basco, Calabrò \& Campopiano, 2018). More details on STEP's academic contributions and references will be discussed in the "Theoretical Framework" section of this research paper.

The Cross Cultural \& Strategic Management (CCSM), is an interdisciplinary, peer-reviewed academic journal that publishes high impact global cross cultural and strategic management research. CCSM has acknowledged that the ventures and businesses created by families are the most dominant type of business worldwide (Basco, Calabrò \& Campopiano, 2018). CCSM has since stepped up their initiatives into family business research and is actively drawing more submissions on the area to their journal (Au, 2018).

Entrepreneurship Theory and Policy (ETP)is one of the many journals that have devoted special issues to family business research, such as the issue of "Governance Mechanisms and Family Firms". It is the 14th special issue on family enterprise theories published in the ETP journal (Chrisman, Chua, Le Breton-Miller, Miller \& Steier, 2018).

$\mathrm{Au}$ (2018) has identified based on a systematic review on the literature of family business research that the available studies has increased over the past few years. It is therefore clear from the literature review that the area of family business succession and family business research in general is much needed to provide in-depth academic comprehension and positive practical implications. 
Tarulevicz (2018) published a journal article examining the aging hawker crisis in Singapore and reviewing actions of the Singaporean government in addressing this issue. The article agrees that a change in status for hawking by image overhaul is necessary for improving public perception and survival of hawking for the future.

Wang, Lo \& Weng (2019) examined the issue of business succession and analyzed the impact of successor knowledge and successor willingness on corporate sustainable innovation and successful business succession. Sustainable innovation in the context of this study is defined as protecting the inherent values of a business and supporting the sustainability of that business through appropriate successors.

\subsubsection{Linkage of study variables in the conceptual framework}

The literature review has identified common factors that various studies have concluded to have an effect on family business succession. They are: preparation level of successor (Lam, 2007; Castillo, 2006; Lorna, 2010; Sardeshmukh \& Corbett, 2011), planning activities (Miller et al.,2003; Castillo, 2006; Sardeshmukh \& Corbett, 2011), family relationship (Lorna, 2010; Castillo 2006), environment (Lorna, 2010; Kuratko et al., 2004; westhead, 2003). These factors have been identified to have an effect on family business succession as they have been constantly used and researched in past research, they have thus been chosen to make the conceptual framework of this study on family hawking business succession in Malaysia.

In addition to the above, Mokhber et al., (2017) investigated the influence of succession planning factors on the performance of Malaysian SMEs by quantitative research; the study found that both preparation level of heir and the relationship between family members have a positive relationship to overall family business succession and thus performance. Kaunda \& Nkhoma (2013) showed that conflicts may have devastating effects during the succession process in a family business. Positive relationship between families and good communication are also needed for effective succession (Helin \& Jabri, 2016). 
In addition to the studies mentioned above, environment has not been thoroughly explored in most of the past academic studies even though it has been mentioned in the theoretical frameworks used in the research of family business succession. A critical review has been carried out on the effects of environment on family business succession, with priority to the food hawking business. It has been stated that work environment for food hawking is demanding, the work carried out by hawkers are laborious (Chong, 2019). An interview conducted by independent media publisher, The Smart Local Singapore revealed that Singaporean hawkers are faced with the challenge of hot, small and cramped environments (Kei, 2015). This shows that vending environment might have an influence on the family hawking business succession.

A survey interview on food hawker working hours in Penang found that $65 \%$ of hawkers operate their hawking business at no less than 7 hours daily. $84 \%$ of the $75 \%$ open 6 days a week, this does not account for preparation and closing (Chong, 2019). Kei (2015) has identified through an interview with hawkers In Singapore that the long operating hours cannot be helped given the increasing costs of living in Singapore. There are also ongoing efforts by the Singapore National Environment Agency to reduce the number of mandatory opening days from six days a week to five as well as changing the minimum operating hours to better accommodate hawkers (Sim, 2018). This shows that operating hours may also affect family hawking business succession.

Many studies have also shown a correlation between working environment satisfaction and job satisfaction, which may have an effect on business succession. Raziq \& Maulabakhsh (2015) mentioned that the physical working environment or social working conditions may affect job satisfaction in organisations; the same study also said that working hours can affect job satisfaction. Lane, Esser, Holte, \& Mccusker, (2010) has also stated that working hours may affect job satisfaction. Several businesses that choose to ignore the working environment will also result in adverse effects on employee performance; A Danish study found that that a firm can increase productivity through the improvement of the physical dimensions of the working environment (Razaiq \& Maulabakhsh, 2015). Bakotić \& Babić, (2013) concluded in their study that workers who worked under harsh working conditions were found to be dissatisfied with their jobs, the study stated that this would be solved by improving working conditions. Although these studies were not done in the context of family business succession, they provide insight 
into the role of working environment and operating hours on job satisfaction, which may influence business succession. Badawy, Alaadin \& Magdy (2016) found a positive correlation between job satisfaction and succession planning, which may be an indication of increasing intention of business succession when job satisfaction is increased.

Tarulevicz (2018) has also reported in their review that most current young hawkers had high position jobs before choosing to become hawkers voluntarily. The article reports on many individuals such as bankers, engineers and marketing specialists who willingly gave up their jobs for their family's hawker business. The article also mentions that they do not mind if the hawker venture fails but possess deep passion and courage to pursue hawking. This indicates that successor willingness plays a huge role in determining family hawker business succession as one would be willing to succeed a family hawker business through personal values and passion.

Kok (2018) reported that many hawkers were not satisfied with the long working hours, low wages and non-existent employment benefits. The article also stated that young Singaporean hawkers did not see the benefit of working in a hot and cramped environment with low profit.

Majority of existing studies have assumed that the family business is no longer involved in management. As a result, the conceptual framework used separates ownership and management, this is not applicable to small family businesses. A conceptual framework has been constructed in reference to past literature for this study.

Wang, Lo \& Weng, (2019) hypothesized in their study that the independent variables of successor knowledge and succession willingness are positively correlated to the dependent variable of sustainable innovation or successful family business succession. The study also hypothesized that leader approval or the incumbent family leader's approval would act as a moderating variable that has a positive interference between both successor knowledge and succession willingness. The study found that leader approval has no significant impact on successor knowledge but has significant positive impact on succession willingness. In other words, the leadership positions of family businesses held by elders are often not willing to delegate power, thus, the leader's willingness to delegate power and to approve of the successor is of great importance to 
the successor's willingness to succeed in the family business. Hench, leader approval will be examined in this study as a moderator variable between the interdependent variable of successor willingness and the dependent variable of family business succession in the food hawking business in Malaysia.

Successor willingness as an independent variable and leader approval as a moderating variable will be included in the conceptual framework of this study; as both variables have been examined by Wang, Lo \& Weng (2019) and were found to be significant towards successful family business succession.

\subsection{THEORETICAL FRAMEWORK}

Theoretical frameworks and academic approaches related to family business succession used in the available literature include agency costs theory, resource-based theory (RBV), corporate entrepreneurship strategy stewardship theory, and behavioural agency theory (Perri \& Peruffo, 2017).

The agency theory states that an agent or individual can act in his or her own interest as opposed to the interest of principal, this will result in moral and decision problems, this will lower the economic standing of the company as additional costs are needed for incentives and management change (Eisenhardt, 1989). However, when ownership and management converge and family is involved, this becomes less of an issue (Eisenhardt, 1989). Family firms can reduce the negative effects of agency theory as parents are generous towards their children. Family managers tend to act out of family generosity than for incentives (Chen \& Nowland, 2010). The key points here are relationship among family members and planning activities, which can potentially reduce the agency problems.

The resource-based theory is also relevant to family businesses. It states that different resources lead to varying degree of performance of a company, the business value depends on resource management (Barney, 1991). It is proposed that successful family firms are a result of strategic management of family traits such as having good 
family relationship, increasing productivity (Zellweger, Nason \& Nordqvist, 2011). Other studies have shown that traits such as loyalty and respect contribute to family business success (Hoffman, Hoelscher \& Sorenson, 2006). This theory involves preparation level of heir and family relationship, family managers feel motivated by family and improve employee interaction and prepares the family business heir for success.

The stewardship theory states that in a business, the agent is internally motivated by being in a family business as opposed to being opportunistic in the agency theory and hence act as stewards (Le Breton-Miller \& Miller, 2009). Family managers feel a sense of belonging in the firm, non-family managers being led by family owners reciprocate this relationship and work with each other to a common goal (Pearson \& Marler, 2010). Relationship with family members is the main point that this theory highlights.

Family business succession has also been qualitatively researched by the Successful Transgenerational Entrepreneurship Practices (STEP) global research consortium founded by scholarly affiliates; this research project has introduced the concept of transgenerational entrepreneurship. The transgenerational entrepreneurship concept has been defined as the "processes that a family uses to develop entrepreneurial qualities and unique family capabilities that lead to new entrepreneurship value across generations" (Basco, Calabrò \& Campopiano, 2018).

The concept integrates two main academic theories or approaches that STEP deems best fit the theories for family business succession research. The two academic theories or approaches integrated are: firstly, the resource-based view as mentioned previously; family business competitive advantage is gained by the ability of family businesses to create, sustain and utilise unique and not easily imitated resources and capabilities (Basco, Calabrò \& Campopiano, 2018). The second academic approach is the corporate entrepreneurship strategy; this strategy emphasizes on innovation and entrepreneurship activities. Corporate entrepreneurship strategy enables an established business to develop novel ideas and opportunities for the continual improvement of organisational processes and competitive advantage (Zur \& Walega, 2015). A company is said to carry out corporate entrepreneurship in order to enhance knowledge-based capital, improve innovation or to exploit business opportunities (Afshar Jahanshahi, Nawaser \& Brem, 2018). In the context of family business, corporate entrepreneurship 
ensures that family businesses are able to leverage and transfer the unique resources of family entrepreneurial thinking skills for future innovation and success.

The transgenerational entrepreneurship concept can be viewed as STEP's conceptual framework for family business succession which combines both theoretical frameworks of resource-based view and corporate entrepreneurship strategy. The resource-based view suggests that unique family entrepreneurial mindsets emerge from family relationship and their interaction with the family business. The family relationship and interactions are seen as unique, inimitable, rare and valuable resources which leads to sustainable competitive advantage. The resource-based view is necessary but not sufficient for family businesses to be successful over generations; family businesses must also ensure the establishment of processes to leverage the said unique resources. In other words, a family business will not succeed with the resources alone but will require an entrepreneurial orientation to put the resources to good use. This is hence why the corporate entrepreneurial strategy has been integrated into the transgenerational entrepreneurship concept. The corporate entrepreneurial strategy ensures that family businesses develop sound entrepreneurial qualities and objectives which will enable future generations to use the unique resources for sustainable competitive advantage and ensure family business sustainability (Basco, Calabrò \& Campopiano, 2018).

In respect to all the theoretical frameworks discussed here, the resource-based view is deemed the most dominant theoretical framework for this study; as RBV can best support and explain the relationship of the independent variables and the dependent variable. RBV has also been used in previous family business research as seen by STEP and can be supported by prior research. Therefore, the RBV will serve as the supporting theoretical framework for this research study. 


\subsection{CONCEPTUAL FRAMEWORK}

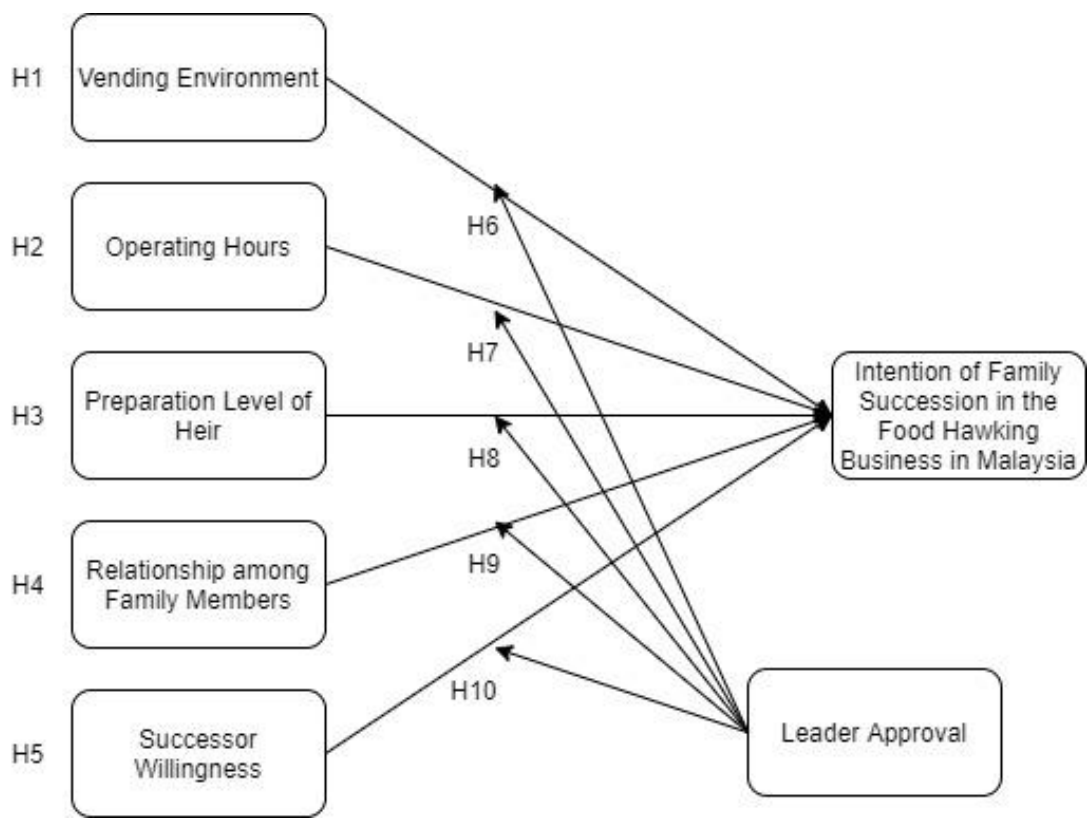

FIGURE 2.1 The Conceptual Framework

\subsection{HYPOTHESES}

H1: Vending environment affects family succession in the food hawking business of Malaysia.

$\mathrm{H} 2$ : Operating hours affect family succession in the food hawking business of Malaysia.

H3: Preparation level of heir affects family succession in the food hawking business of Malaysia.

H4: Relationship among family members affect family succession in the food hawking business of Malaysia. 
H5: Successor willingness affects family succession in the food hawking business of Malaysia.

H6: The relationship between vending environment and family succession in the food hawking business of Malaysia will be stronger when leader approval is strong.

H7: The relationship between operating hours and family succession in the food hawking business of Malaysia will be stronger when leader approval is strong.

H8: The relationship between preparation level of heir and family succession in the food hawking business of Malaysia will be stronger when leader approval is strong.

H9: The relationship between relationship among family members and family succession in the food hawking business of Malaysia will be stronger when leader approval is strong.

H10: The relationship between successor willingness and family succession in the food hawking business of Malaysia will be stronger when leader approval is strong. 


\section{RESEARCH METHODOLOGY}

\subsection{RESEARCH DESIGN}

A questionnaire survey was administered with the aim of investigating the factors of vending environment, operating hours, public perception, preparation level of heir, relationship among family members, planning activities, successor willingness and leader approval on family succession in the food hawking business in Malaysia. The heirs/successors of food hawker businesses in Malaysia were chosen as the unit of analysis, as they are the targeted population for this study. A self-administered questionnaire was used as the instrument for the collection of empirical data from the unit of analysis.

This study was a quantitative and cross-sectional study. A cross sectional approach was selected for this study due to the lack of time; this also allows for the collection of complete information without a long wait period (Bahrick, Bahrick \& Wittlinger, 1975). Furthermore, follow-up is not necessary in a cross-sectional study and thus is faster, cost effective and less resource intense (Mann, 2003).

Regarding the ethical considerations of this study; a consent form was developed and survey approval obtained from the appropriate postgraduate school ethics committee and entities with the UCSI institution. Research participants was informed of their rights and was required to provide consent by an attached form before proceeding to the survey. The appropriate information was disclosed in the consent form. The survey study is voluntary and anonymous in nature; all collected information was kept strictly confidential and only used for the sole purpose of this research study. Participants were allowed to stop participating in the survey at any time should they feel any discomfort or have a change of mind. Participating in the research poses no foreseeable harm.

\subsection{SAMPLING}




\subsubsection{Target Population}

The target population was the heirs/successors of food hawker businesses in Malaysia, as the successors will give the appropriate information regarding the factors that affect family business succession in the food hawking business Malaysia; this yielded the relevant information to test the study hypotheses.

\subsubsection{Sampling Method}

Non-probability convenience sampling was chosen to be the sampling method due to the ease of execution, cost effectiveness and time efficiency given the limited time duration (Jager, Putnick \& Bornstein, 2017). Convenience sampling was also the most suitable sampling method for this study as there are no official Malaysian records that show how many family-owned hawker businesses there are in Malaysia. There are no additional criteria to convenience sampling except that the individual be available and willing to participate (Saunders, Lewis \& Thornhill, 2012). Snowball sampling method where one respondent provides the researcher with at least one more potential respondent was also be used to secure respondents (Kirchherr \& Charles, 2018).

\subsubsection{Sampling Location}

The sampling location at which data collection was carried out was Kuala Lumpur and Penang island. The sampling location was such because hawkers are abundant and scattered all over Kuala Lumpur and Penang island. As mentioned, Penang has been said to be the world's best street food destination (New Straits Time, 2016; Time Magazine, 2004). Kuala Lumpur is also famous for its dense hawker centres such as the famous Jalan Alor street at Bukit Bintang (Time Out KL, 2014). 


\subsubsection{Sampling Size}

The rule of thumb for recommended sample size ranges from the item-response ratio of 1:4 to 1:10 (Hinkin, 1995; Boateng, Neilands, Frongillo, Melgar-Quiñonez \& Young, 2018). Hence, the appropriate sample size for this study ranged from 148 to 370 respondents.

\subsection{VARIABLE MEASUREMENT}

\subsubsection{Research Instrument}

The questionnaire consisted of 9 sections including the demographic profile section. Measurements were adapted from those of Hampel-Milagrosa, Loewe \& Reeg, (2015), Wang, Lo \& Weng, (2019), Pritchett et al., (2010), Lepold, Tanzer, Bregenzer \& Jiménez, (2018), Raziq \& Maulabakhsh, (2015), Walsh, Beatty \& Shiu, (2009), Coffman, (2014) and Perret, (2016). Table 3.1 shows the operationalisation of variables and their respective sources. 
TABLE 3.1 Operationalization of Variables

\begin{tabular}{|c|c|c|}
\hline Variables & Operationalization of variables & Reference scale \\
\hline $\begin{array}{l}\text { Preparation level of } \\
\text { heir }\end{array}$ & $\begin{array}{l}\text { Successor knowledge scale (6 items in } \\
\text { total) }\end{array}$ & $\begin{array}{l}\text { (Hampel- } \\
\text { Milagrosa, Loewe } \\
\text { \& Reeg, 2015) } \\
\text { (Wang, Lo \& } \\
\text { Weng, 2019) }\end{array}$ \\
\hline $\begin{array}{l}\text { Relationship among } \\
\text { family members }\end{array}$ & $\begin{array}{l}\text { Family adaptation, partnership, growth, } \\
\text { affection and resolve (APGAR) scale ( } 5 \\
\text { items in total) }\end{array}$ & $\begin{array}{l}\text { (Pritchett et al., } \\
2010)\end{array}$ \\
\hline $\begin{array}{l}\text { Vending } \\
\text { environment }\end{array}$ & $\begin{array}{l}\text { Profile Analysis of Job Satisfaction } \\
\text { (PAJS) scale ( } 2 \text { items in total) } \\
\text { Republic Of Macedonia State Statistical } \\
\text { Office Employee Satisfaction Survey } \\
\text { scale (1 item in total) }\end{array}$ & $\begin{array}{l}\text { (Lepold, Tanzer, } \\
\text { Bregenzer \& } \\
\text { Jiménez, 2018) } \\
\text { (Raziq \& } \\
\text { Maulabakhsh, } \\
\text { 2015) }\end{array}$ \\
\hline Operating hours & $\begin{array}{l}\text { Profile Analysis of Job Satisfaction } \\
\text { (PAJS) scale (4 items in total) }\end{array}$ & $\begin{array}{l}\text { (Lepold, Tanzer, } \\
\text { Bregenzer \& } \\
\text { Jiménez, 2018) }\end{array}$ \\
\hline $\begin{array}{l}\text { Successor } \\
\text { willingness }\end{array}$ & $\begin{array}{l}\text { Succession willingness scale (6 items in } \\
\text { total). }\end{array}$ & $\begin{array}{l}\text { (Wang, Lo \& } \\
\text { Weng, 2019) }\end{array}$ \\
\hline Leader approval & Leadership scale (5 items in total). & $\begin{array}{l}\text { (Walsh, Beatty \& } \\
\text { Shiu, 2009) } \\
\text { (Wang, Lo \& Weng, } \\
\text { 2019) }\end{array}$ \\
\hline Intention of family & Extensiveness of Business Succession & (Coffman, 2014) \\
\hline $\begin{array}{l}\text { succession in the } \\
\text { food hawking } \\
\text { business in Malaysia }\end{array}$ & $\begin{array}{l}\text { Preparedness Scale ( } 2 \text { items in total) } \\
\text { Successful succession score scale ( } 5 \\
\text { items in total) }\end{array}$ & (Perret, 2016) \\
\hline
\end{tabular}

The operational definition of each variable along with the respective sources is further presented in table 3.2. 
TABLE 3.2 Operational Definition of Variables

\begin{tabular}{|c|c|c|}
\hline Variables & Operational definition of variables & Reference scale \\
\hline $\begin{array}{l}\text { Preparation level of } \\
\text { heir }\end{array}$ & $\begin{array}{l}\text { The extent to which heirs have the } \\
\text { requisite business skills, managerial } \\
\text { capabilities, knowledge of company } \\
\text { operations, and attitudinal predisposition } \\
\text { prior to assuming control of the business } \\
\text { to ensure the smooth running of the } \\
\text { business. }\end{array}$ & $\begin{array}{l}\text { (Hampel- } \\
\text { Milagrosa, Loewe } \\
\text { \& Reeg, 2015) } \\
\text { (Wang, Lo \& } \\
\text { Weng, 2019) }\end{array}$ \\
\hline $\begin{array}{l}\text { Relationship among } \\
\text { family members }\end{array}$ & $\begin{array}{l}\text { The degree to which family functions } \\
\text { such as family adaptation, partnership, } \\
\text { growth, affection and resolve are evident } \\
\text { in the family of an individual that } \\
\text { contribute to family connectedness. }\end{array}$ & $\begin{array}{l}\text { (Pritchett et al., } \\
2010)\end{array}$ \\
\hline $\begin{array}{l}\text { Vending } \\
\text { environment }\end{array}$ & $\begin{array}{l}\text { The degree of satisfaction with the } \\
\text { physical working conditions including } \\
\text { the spaciousness, current maintenance of } \\
\text { the premise and working tools. }\end{array}$ & $\begin{array}{l}\text { (Lepold, Tanzer, } \\
\text { Bregenzer \& } \\
\text { Jiménez, 2018) } \\
\text { (Raziq \& } \\
\text { Maulabakhsh, } \\
\text { 2015) }\end{array}$ \\
\hline Operating hours & $\begin{array}{l}\text { The degree of satisfaction with the } \\
\text { working hours while taking into } \\
\text { consideration break times, vacation } \\
\text { times and the wishes of an individual in } \\
\text { organising the working hours. }\end{array}$ & $\begin{array}{l}\text { (Lepold, Tanzer, } \\
\text { Bregenzer \& } \\
\text { Jiménez, 2018) }\end{array}$ \\
\hline $\begin{array}{l}\text { Successor } \\
\text { willingness }\end{array}$ & $\begin{array}{l}\text { The extent to which successors are } \\
\text { willing to effectively take over the } \\
\text { responsibility in the family business. }\end{array}$ & $\begin{array}{l}\text { (Wang, Lo \& } \\
\text { Weng, 2019) }\end{array}$ \\
\hline Leader approval & $\begin{array}{l}\text { The degree to which the leader is } \\
\text { effectively willing to transfer } \\
\text { responsibility and authority to others. }\end{array}$ & $\begin{array}{l}\text { (Walsh, Beatty \& } \\
\text { Shiu, 2009) } \\
\text { (Wang, Lo \& } \\
\text { Weng, 2019) }\end{array}$ \\
\hline
\end{tabular}




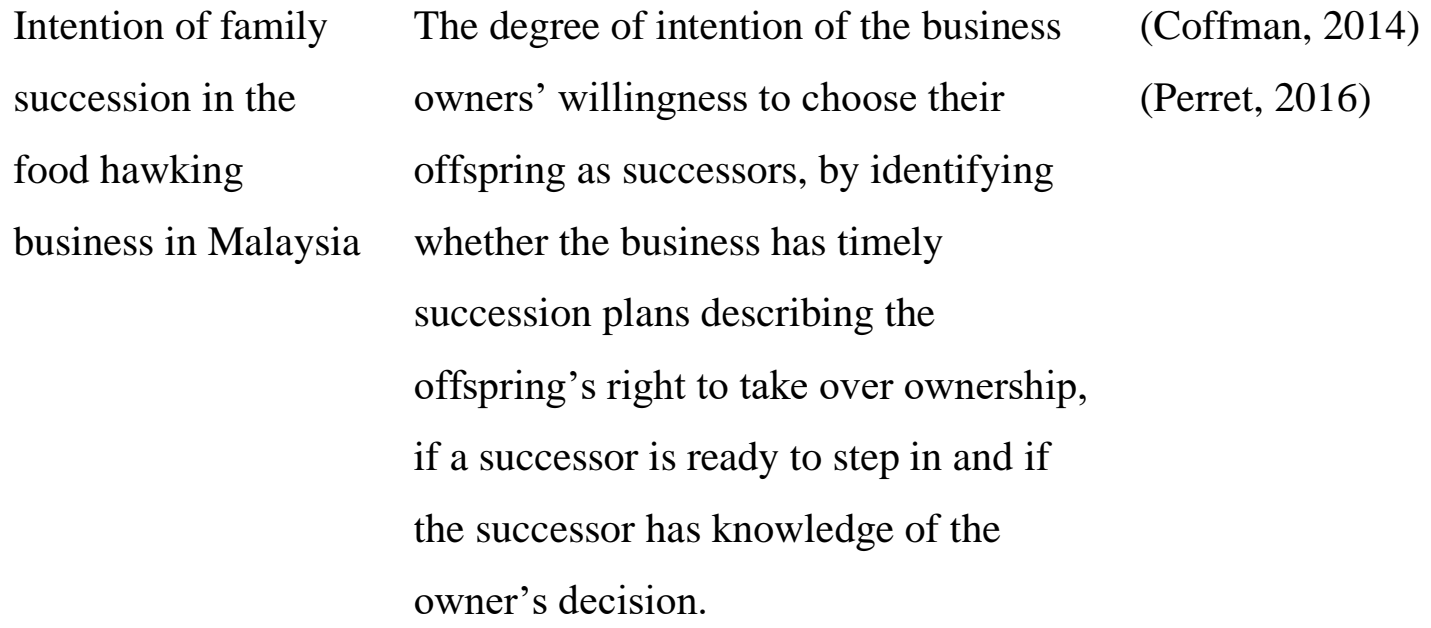

The questions and statements of the questionnaire were translated into Chinese to promote comprehension. The translation was done by means of back translation; a process where a text is translated into a target language and then re-translated back to the original language by another translator who is unaware of the original text (Tsang, Royse $\&$ Terkawi, 2017). This process was then repeated if discrepancies were found between the original text and the back-translated text. The translated text was then considered to have the same meaning as the original text.

A pre-test was conducted by consultation with various individuals in the hawker business as they were representative of the target population, this was done to ensure the items are meaningful to the target population before the full-scale survey was carried out. Pre-testing is said to ensure: (a) confusing questions are identified and improved for clarity, (b) questions that are difficult to answer are identified and corrected, (c) questions are producing the intended data (Boateng, Neilands, Frongillo, Melgar-Quiñonez \& Young, 2018). Pre-testing has helped eliminate poorly worded items and word revision to ensure maximum comprehension by the target population. Two items were dropped and five items were reworded after the pre-test interview was carried out. Modifications were also made to the grammar and words for better understanding.

A pilot test was also carried out to ensure the reliability and internal consistency of the questionnaire. Reliability refers to the degree of consistency shown when measurements are repeated under identical conditions (Boateng, Neilands, Frongillo, Melgar-Quiñonez \& Young, 2018). The recommended sample size for the pilot test was 
said to be $10 \%$ of the projected sample size for the large parent study (Connelly, 2008; Whitehead, Julious, Cooper \& Campbell, 2015). Hence, the appropriate sample size for the pilot test for this study was 15 to 37 respondents, considering the appropriate sample size for this study ranges from 148 to 370 respondents as mentioned earlier. An alpha value of 0.60 to 0.70 is considered moderate and an alpha value of 0.70 and above is considered optimal (Taber, 2017). A sample size of 35 respondents was obtained for the pilot test. Table 3.3 shows the Cronbach Alpha results from the pilot test, the values range from 0.809 to 0.911 . All variables have fulfilled the reliability test and are considered to be of optimal value according to Taber, (2017).

TABLE 3.3 Cronbach's Alpha Values of Pilot Test

\begin{tabular}{lc}
\hline \multicolumn{1}{c}{ Variables } & Cronbach's Alpha Value \\
\hline Vending Environment (VE) & 0.876 \\
Operating Hours (OH) & 0.859 \\
Preparation Level of Heir (PH) & 0.815 \\
Relationship Among Family Members & 0.870 \\
(RE) & \\
Successor Willingness (SW) & 0.911 \\
Leader's Approval (LA) & 0.908 \\
Intention of Family Succession in the & 0.809 \\
Food Hawking Business in Malaysia & \\
(DV) & \\
\hline
\end{tabular}

\subsection{DATA COLLECTION}

The types of data relevant to this research include primary data and secondary data, as both will be collected and used throughout this study. Primary data was collected through the questionnaire survey. Secondary data on the other hand was obtained from literature; journals, research papers, news articles and text from the appropriate credible sources. 
For primary data, self-administered questionnaires of five-point Likert scale was used to collect primary data from the sample population for this study. This is a cross sectional quantitative study, as such, a questionnaire is the most appropriate considering the limited time available. Questionnaires are also easier to administer, time efficient and economical in nature (Mann, 2003).

For secondary data, primary studies and research papers were collected by conducting a database search on electronic online databases. Such as Emerald Management, ScienceDirect, Scopus, Springer etc. The search was performed by using the appropriate key words and Boolean operators for a more efficient search. AND, OR and NOT are Boolean operators named after mathematician George Boole and was used ("George Boole | British mathematician", 2019).

\subsection{DATA ANALYSIS METHOD}

\subsubsection{Descriptive Statistics}

Descriptive statistics was used to describe and illustrate the characteristics of respondents such as age, sex, race, monthly income, highest educational level and marital status. This information was presented using a table of frequency and percentage. The central tendencies and dispersion of the variables were also measured. The mean measured the average score of each variable, the standard deviation showed the deviation between the data findings and the mean. (Saunders, Lewis \& Thornhill, 2012).

\subsubsection{Reliability Test}

Reliability Testing or internal consistency analysis was used to test the reliability of the respective constructs by Cronbach's Coefficient Alpha. 
Cronbach's Alpha was used to ensure variable inter-correlation or internal consistency of the questionnaire survey. Taber (2017) argues based on a meta-analysis and critical review that researchers should strive for an alpha value of 0.70 and above; alpha values of 0.60 to 0.70 are considered moderate.

\subsubsection{Normality Test}

Normality testing was used to identify if the data set is normally distributed as the collected data must obey parametric tests assumptions for parametric testing. Skewness and kurtosis testing were performed to test normality of the collected data. Kline (2011) stated that the acceptable deviation of data from normality is within the range of \pm 3 for skewness and \pm 10 for kurtosis.

\subsubsection{Pearson's Correlation Analysis}

Pearson's correlation analysis was conducted to measure the correlation between the variables. Pearson's correlation analysis was used to identify the strength and direction of the linear relationship between the dependent variable (Intention of Family Succession in the Food Hawking Business in Malaysia) and the independent variables or predictors (vending environment, operating hours, preparation level of heir, relationship among family members and successor willingness).

Pearson's correlation analysis can also identify multicollinearity which is said to occur if the coefficient value between independent variables exceed 0.9 (Rhoton, 2014). 


\subsubsection{Multiple Linear Regression Analysis (MLR)}

Multiple linear regression analysis was used to analyse the multivariate relationship of the independent variables and the dependent variable. Multiple linear regression was used for assessing relationships between the dependent variable and the independent variables that allows the prediction of outcomes of the dependent variable using a linear combination of independent variables.

Multiple linear regression analysis was carried out as the collected data fulfils the assumptions of MLR analysis; reliability, normality and multicollinearity. This study is considered a complex model as it possesses five independent variables and is best analysed using MLR analysis (Gunzler \& Morris, 2015). The relationship between the dependent variable and the independent variables is considered to be significant if the pvalue of the particular IV is less than 0.05 (Saunders, Lewis \& Thornhill, 2012).

\subsubsection{Moderation Analyses}

A moderator variable is defined as a variable that modifies the strength of relationship between an independent variable and a dependent variable (MacKinnon, 2011). A moderator variable of leader approval has been included in this study to acknowledge the complex relationship of the independent and dependent variables in the conceptual model of this study. The moderator variable has tested the theory of moderation of leader approval on the relationship between independent variables (vending environment, operating hours, preparation level of heir, relationship among family members and successor willingness) and the dependent variable (Intention of Family Succession in the Food Hawking Business in Malaysia) as mentioned in the literature review.

Moderation analysis was conducted by SPSS in order to investigate the moderating effects of leader approval on the relationship between the independent variables (vending environment, operating hours, preparation level of heir, relationship 
among family members and successor willingness) and the dependent variable (Intention of Family Succession in the Food Hawking Business in Malaysia). The moderating effect of leader approval was tested in multiple regression by the creation of a third variable by multiplying $\mathrm{M}$ (moderator variable value) by $\mathrm{X}$ (independent variable value) to form the interaction term $\mathrm{X}^{*} \mathrm{M}$. The coefficient $\mathrm{X}^{*} \mathrm{M}$ showed how much the coefficient for the relationship between X (independent variable value) and Y (dependent variable value) changes per unit of M (Whisman \& McClelland, 2005). 


\section{DATA ANALYSIS}

\subsection{INTRODUCTION}

Statistical Products and Service Solutions 25 (SPSS) software was used to perform the statistical analyses from the collected data. This section will present results of the descriptive analysis, scale reliability and inferential analysis (Pearson's correlation analysis, multiple linear regression analysis). These results will then be used in the decision to accept or reject the research hypotheses.

\subsection{DESCRIPTIVE ANALYSIS}

\subsubsection{Demographic Profile of Respondents}

The demographic information yielded from the questionnaire includes the respondent's sex, age, race, highest education level, marital status, total monthly household income and state.

Figure 4.1 shows the frequencies and percentages of the sex of all 208 respondents. $46.6 \%$ are female, $53.4 \%$ are male. 


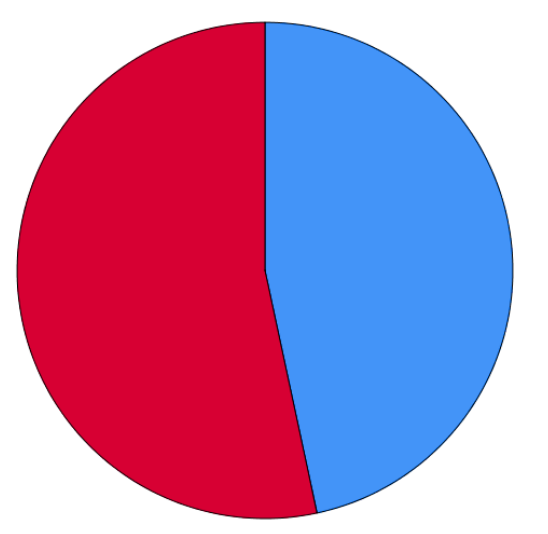

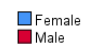

FIGURE 4.1 Sex

Figure 4.2 shows the frequencies and percentages of the ages of all 208 respondents. $20.2 \%$ are 25 years or less, $11.5 \%$ are 26 to 30 years, $29.8 \%$ are 31 to 40 years, $18.8 \%$ are 41 to 45 years and $19.7 \%$ are above 45 years.

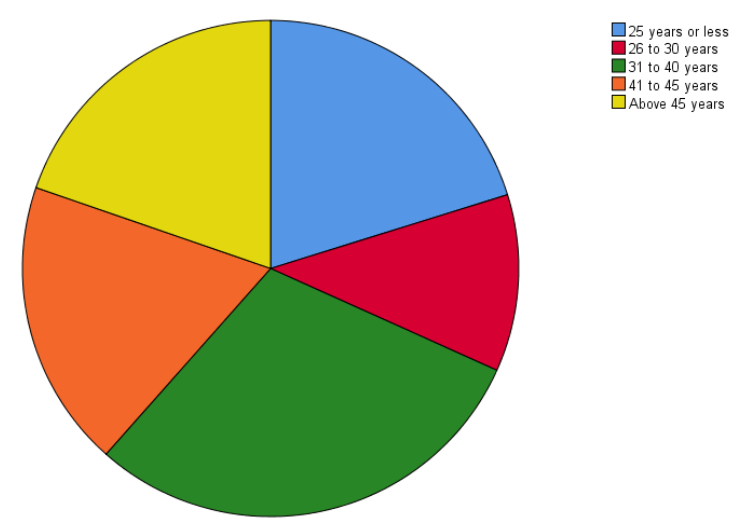

FIGURE 4.2 Age

Figure 4.3 shows the frequencies and percentages of the races of all 208 respondents. $68.8 \%$ are Chinese, $10.6 \%$ are Indian, $19.7 \%$ are Malay and $1 \%$ are of other races. 


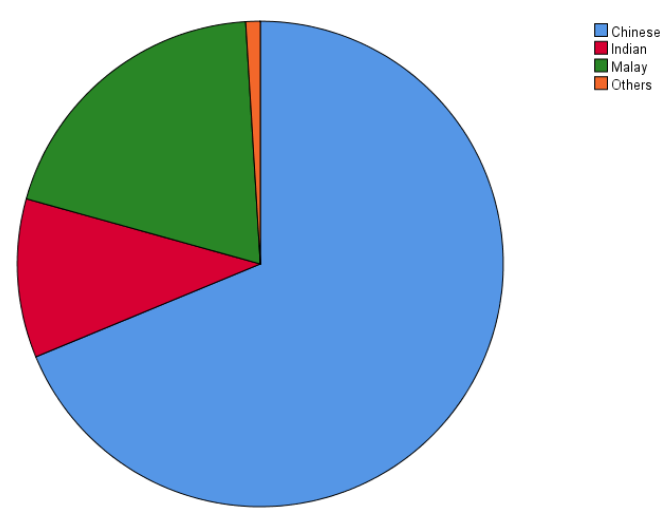

FIGURE 4.3 Race

Figure 4.4 shows the frequencies and percentages of the highest education levels of all 208 respondents. $1 \%$ are less than primary educated, $13 \%$ are primary educated, $70.2 \%$ are secondary educated, $2.9 \% \%$ are diploma holders and $13 \%$ are bachelor degree holders.

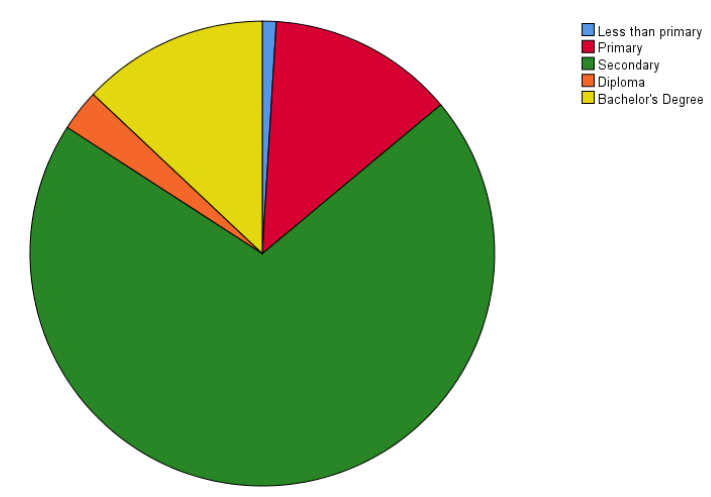

FIGURE 4.4 Highest Level of Education

Figure 4.5 shows the frequencies and percentages of the total monthly household incomes of all 208 respondents. 23\% earn below RM2500, 55.8\% earn RM2500 to RM6500, $10.1 \%$ earn RM6500 to RM10500, 8.7\% earn RM10500 to RM14500 and $1.9 \%$ earn RM14500 to RM18500. 


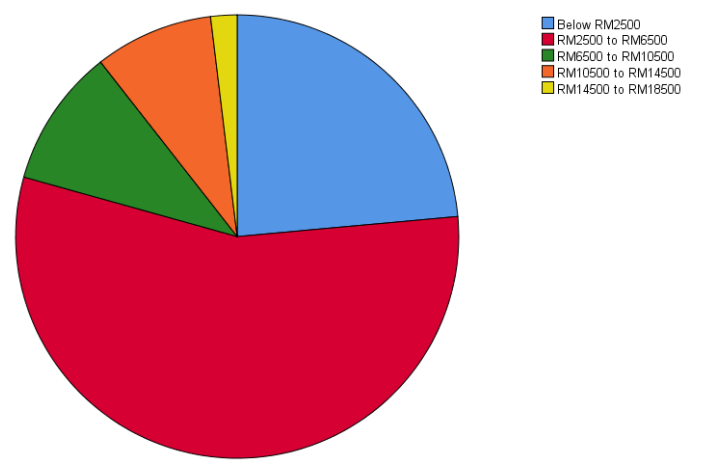

\section{FIGURE 4.5 Total Monthly Household Income}

Figure 4.6 shows the frequencies and percentages of the state of all 208 respondents. $14.9 \%$ are from Kuala Lumpur and $85.1 \%$ are from Penang.

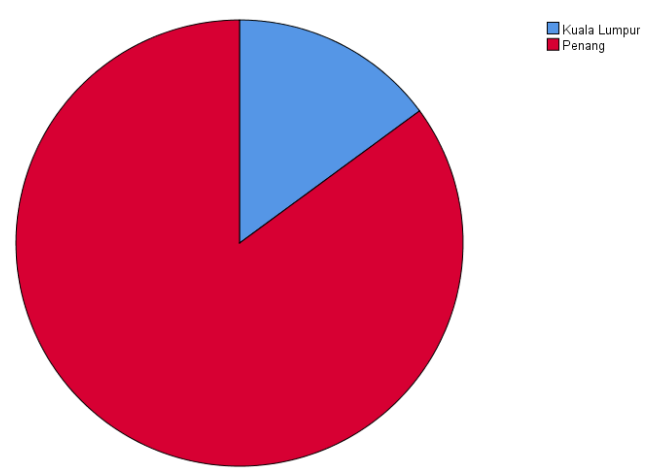

FIGURE 4.6 State

Figure 4.7 shows the frequencies and percentages of the marital statuses of all 208 respondents. $64.4 \%$ are married, $33.2 \%$ are single and $2.4 \%$ are divorced.

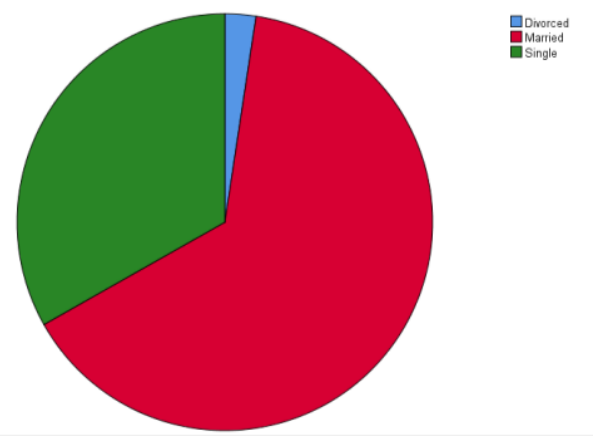

FIGURE 4.7 Marital Status 
Table 4.1 shows the frequencies and percentages of the demographic information of all 208 respondents.

TABLE 4.1 Demographic Information of Respondents

\begin{tabular}{|c|c|c|c|}
\hline Variables & Category & Frequency & Percentage (\%) \\
\hline \multirow[t]{2}{*}{ Gender } & Female & 97 & 46.6 \\
\hline & Male & 111 & 53.3 \\
\hline \multirow[t]{5}{*}{ Age } & 25 years or less & 42 & 20.2 \\
\hline & 26 to 30 years & 24 & 11.5 \\
\hline & 31 to 40 years & 62 & 29.8 \\
\hline & 41 to 45 years & 39 & 18.8 \\
\hline & Above 45 years & 41 & 19.7 \\
\hline \multirow[t]{4}{*}{ Race } & Chinese & 143 & 68.8 \\
\hline & Indian & 22 & 10.6 \\
\hline & Malay & 41 & 19.7 \\
\hline & Others & 2 & 1.0 \\
\hline \multirow[t]{5}{*}{ Education Level } & Less than primary & 2 & 1.0 \\
\hline & Primary & 27 & 13.0 \\
\hline & Secondary & 146 & 70.2 \\
\hline & Diploma & 6 & 2.9 \\
\hline & Bachelor's degree & 27 & 13.0 \\
\hline \multirow{9}{*}{$\begin{array}{l}\text { Total Monthly } \\
\text { Household Income }\end{array}$} & Below RM2500 & 49 & 23.6 \\
\hline & RM2500 to & 116 & 55.8 \\
\hline & RM6500 & & \\
\hline & RM6500 to & 21 & 10.1 \\
\hline & RM10500 & & \\
\hline & RM10500 to & 18 & 8.7 \\
\hline & RM14500 & & \\
\hline & RM14500 to & 4 & 1.9 \\
\hline & RM18500 & & \\
\hline \multirow[t]{2}{*}{ State Residing } & Kuala Lumpur & 31 & 14.9 \\
\hline & Penang & 177 & 85.1 \\
\hline \multirow[t]{3}{*}{ Marital Status } & Married & 134 & 64.4 \\
\hline & Single & 69 & 33.2 \\
\hline & Divorced & 5 & 2.4 \\
\hline
\end{tabular}




\subsubsection{Central Tendencies of Constructs}

Table 4.2 presents the mean and standard deviation scores for all questionnaire items for each construct. The mean for vending environment ranges from 3.39 to 3.52, operating hours range from 3.30 to 3.61 , preparation level of heir range from 3.50 to 3.72 , relationship among family members range from 3.92 to 4.03 , successor willingness range from 3.61 to 3.77 , leader's approval range from 3.43 to 3.70 and the dependent variable of intention of family succession in the food hawking business in Malaysia range from 3.48 to 3.57 . This shows that most item responses were answered with "neutral" or "agree", with exception to "relationship among family members" which indicate were most answered with "agree" or "strongly agree". The standard deviation for all variables lies between the range of 0.814 to 1.116 .

TABLE 4.2 Central Tendencies of Constructs Summary

\begin{tabular}{cccc}
\hline Variables & Items & Mean & $\begin{array}{c}\text { Standard } \\
\text { Deviation }\end{array}$ \\
\hline Vending & VE 1 & 3.49 & 0.973 \\
Environment (VE) & VE 2 & 3.52 & 0.937 \\
& VE 3 & 3.39 & 0.910 \\
Operating Hours & VE 4 & 3.39 & 0.895 \\
(OH) & OH 1 & 3.56 & 1.048 \\
& OH 2 & 3.61 & 1.011 \\
Preparation Level of & OH 3 & 3.47 & 0.997 \\
Heir (PH) & OH 4 & 3.30 & 0.992 \\
& PH 1 & 3.61 & 0.844 \\
& PH 2 & 3.62 & 0.843 \\
Relationship Among & PH 3 & 3.50 & 0.799 \\
Family Members & PH 4 & 3.72 & 0.895 \\
(RE) & PH 5 & 3.62 & 0.865 \\
& PH 6 & 3.62 & 0.825 \\
Successor & RE 1 & 4.00 & 0.814 \\
& RE 2 & 4.03 & 0.892 \\
& RE 3 & 3.92 & 0.903 \\
& RE 4 & 3.95 & 0.872 \\
& RE 5 & 3.94 & 0.869 \\
& SW 1 & 3.62 & 1.005 \\
& & &
\end{tabular}




\begin{tabular}{cccc} 
Willingness (SE) & SW 2 & 3.77 & 1.038 \\
& SW 3 & 3.73 & 1.047 \\
& SW 4 & 3.61 & 1.015 \\
SW 5 & 3.71 & 1.042 \\
Leader's Approval & SW 6 & 3.73 & 0.991 \\
(LA) & LA 1 & 3.47 & 0.873 \\
& LA 2 & 3.70 & 0.958 \\
LA 3 & 3.48 & 0.937 \\
Intention of Family & LA 4 & 3.56 & 0.961 \\
Succession in the & LA 5 & 3.43 & 1.000 \\
Food Hawking & DV 1 & 3.49 & 0.948 \\
Business in Malaysia & DV 2 & 3.57 & 0.981 \\
(DV) & DV 3 & 3.56 & 0.936 \\
& DV 4 & 3.47 & 0.932 \\
& DV 5 & 3.51 & 0.938 \\
& DV 6 & 3.48 & 1.116 \\
& DV 7 & 3.52 & 1.090 \\
\hline
\end{tabular}

\subsection{SCALE RELIABILITY AND NORMALITY}

\subsubsection{Reliability Test}

The collected sample data was subjected to a Cronbach's alpha test in order to test for internal consistency. Table 4.3 shows the Cronbach Alpha results, the values range from 0.896 to 0.947 ; relationship among family members scoring 0.896 and successor willingness scoring 0.947. All variables have fulfilled the reliability test and are considered to be of optimal value according to Taber, (2017).

Table 4.3 Cronbach's Alpha Values of Sample Data

\begin{tabular}{lc}
\hline \multicolumn{1}{c}{ Variables } & Cronbach's Alpha Value \\
\hline Vending Environment (VE) & 0.915 \\
Operating Hours (OH) & 0.921 \\
Preparation Level of Heir (PH) & 0.907 \\
\hline
\end{tabular}


Relationship Among Family Members

0.896

(RE)

Successor Willingness (SW)

Leader's Approval (LA)

0.901

Intention of Family Succession in the

0.942

Food Hawking Business in Malaysia

(DV)

\subsubsection{Normality Test}

Table 4.4 shows the skewness and kurtosis summary for each item in the questionnaire. Measures of kurtosis and skewness can be used to determine the normality of data, acceptable values of skewness ranges from -3 to +3 and kurtosis ranges from -10 to +10 (Kline, 2015). As all items of the questionnaire fulfil these criteria, the sample data is said to be normally distributed.

TABLE 4.4 Skewness and Kurtosis Summary

\begin{tabular}{lccc}
\hline Variables & Items & Skewness & Kurtosis \\
\hline Vending environment & VE 1 & -.213 & -.456 \\
(VE) & VE 2 & -.266 & -.379 \\
& VE 3 & -.075 & -.520 \\
& VE 4 & -.046 & -.614 \\
Operating hours (OH) & OH 1 & -.180 & -.956 \\
& OH 2 & -.206 & -.805 \\
& OH 3 & -.069 & -.695 \\
Preparation level of heir & OH 4 & -.058 & -.608 \\
(OH) & PH 1 & -.328 & -.447 \\
& PH 2 & -.457 & .350 \\
& PH 3 & -.345 & .148 \\
& PH 4 & -.318 & -.601 \\
& PH 5 & -.218 & -.361 \\
Relationship among & PH 6 & -.458 & -.031 \\
& RE 1 & -.589 & -.004
\end{tabular}




\begin{tabular}{llll} 
Family Members (RE) & RE 2 & -.726 & -.139 \\
& RE 3 & -.444 & -.625 \\
& RE 4 & -.480 & -.268 \\
Successor willingness & RE 5 & -.414 & -.568 \\
$($ SW) & SW 1 & -.263 & -.875 \\
& SW 2 & -.441 & -.845 \\
& SW 3 & -.411 & -.900 \\
& SW 4 & -.248 & -.692 \\
Leader's approval (LA) & SW 5 & -.330 & -.950 \\
& SW 6 & -.358 & -.758 \\
& LA 1 & -.006 & -.469 \\
Intention of Family & LA 2 & -.259 & -.715 \\
Succession in the Food & LA 3 & .088 & -.862 \\
Hawking Business in & LA 4 & -.034 & -.805 \\
Malaysia (DV) & LA 5 & -.047 & -.724 \\
& DV 1 & -.161 & -.612 \\
& DV 2 & -.283 & -.547 \\
& DV 3 & -.365 & -.162 \\
& DV 4 & -.132 & -.398 \\
& DV 5 & -.188 & -.553 \\
& DV 6 & -.193 & -.907 \\
\hline
\end{tabular}

\subsection{INFERENTIAL ANALYSIS}

\subsubsection{Model Summary of Multiple Linear Regression Analysis}

Table 4.5 shows the model summary, with an $\mathrm{R}$ square value of 0.643 . This indicates that $64.3 \%$ of the variation in the dependent variable (family succession in the food hawking business of Malaysia) can be explained by the independent variables in the study. Consequently, this also shows that $35.7 \%$ of the variation in the dependent variable is accounted for by other predictor variables that are not tested in this study. From table 4.5, the F-value $(72.913)$ shown is also large with a p-value $(<0.001)$ that is way below 0.05 , indicating a statistically significant result. This indicates that at least one of the five independent variables can be used in modelling the dependent variable; in order words, 
the correlation between the study model and the dependent variable is statistically significant. Hence, model fit is achieved.

TABLE 4.5 Model summary

\begin{tabular}{llll}
\hline Model & R Square & F & Sig. \\
\hline 1 & .643 & 72.913 & $.000 * * *$ \\
\hline$* * * \mathrm{p}<0.001$ & & &
\end{tabular}

\subsubsection{Assumptions for Multiple Linear Regression Analysis}

Table 4.6 shows the tolerance, variance inflation factors and condition index of the independent variables that satisfies the assumption of no multicollinearity. According to Hair et al. (2010) has suggested a tolerance value of greater than 0.1, a variation inflation factor of not more than 10 and a condition index value of not more than 30 to ensure that multicollinearity among independent variables does not exist. As seen in table 4.12, all tolerance values, variance inflation factors and condition index values satisfy these conditions.

TABLE 4.6 Multicollinearity Test

\begin{tabular}{lccc}
\hline Variables & Tolerance & VIF & Condition Index \\
\hline Vending Environment & .274 & 3.646 & 11.506 \\
Operating Hours & .268 & 3.726 & 14.005 \\
Preparation Level of & .426 & 2.350 & 18.896 \\
Heir & & & \\
Relationship Among & .754 & 1.327 & 21.807 \\
Family Members & & & \\
Successor & .624 & 1.604 & 24.731 \\
Willingness & & & \\
\hline
\end{tabular}


Figure 4.8 shows the histogram of the frequency of the dependent variable plotted against the residual of the dependent variable. The bell shape pattern observed in the histogram is characteristics of normally distributed data. As such the assumption of normal distribution for multiple linear regression is fulfilled.

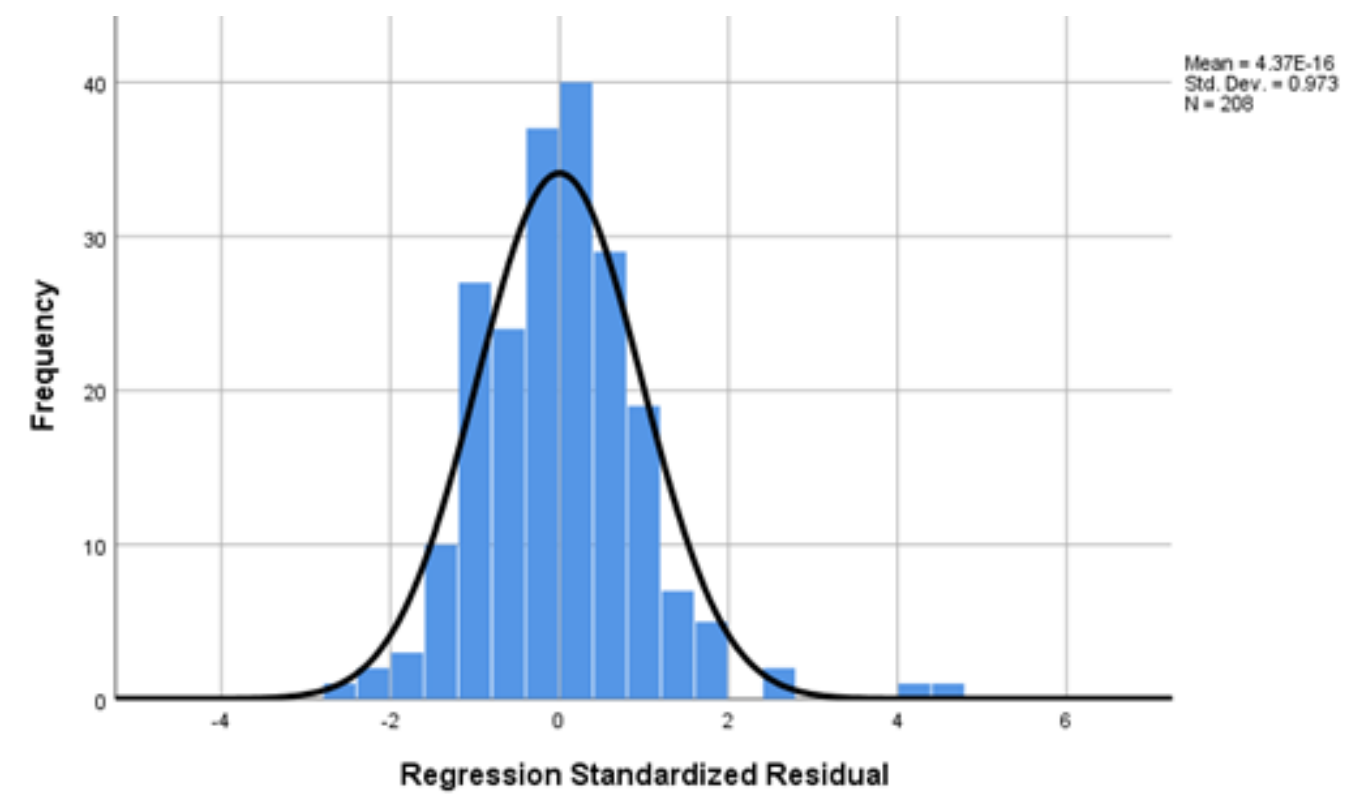

FIGURE 4.8 Histogram for Normality Assumption

Figure 4.9 shows the P-P Plot of regression standardised residual of the dependent variable. The plotted data values appear close to the normal distribution line, indicating once more that the data is normally distributed. 


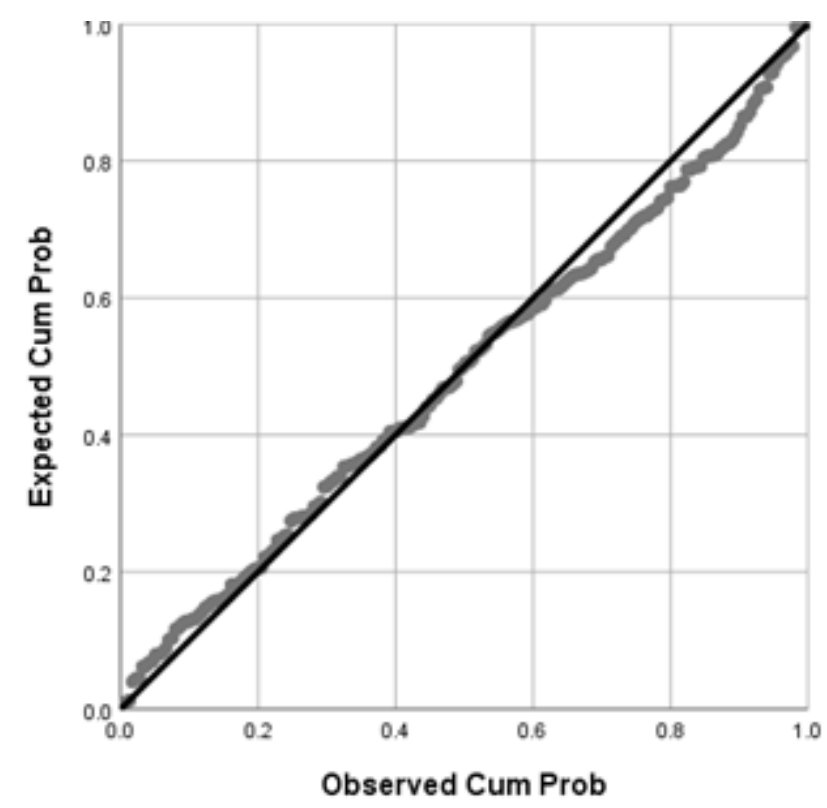

FIGURE 4.9 P-P Plot of Regression Studentised Residual

Figure 4.10 shows the scatterplot of the dependent variable for testing the assumption of homoscedasticity. The data appears random with no obvious patterns, indicating homoscedastic data.

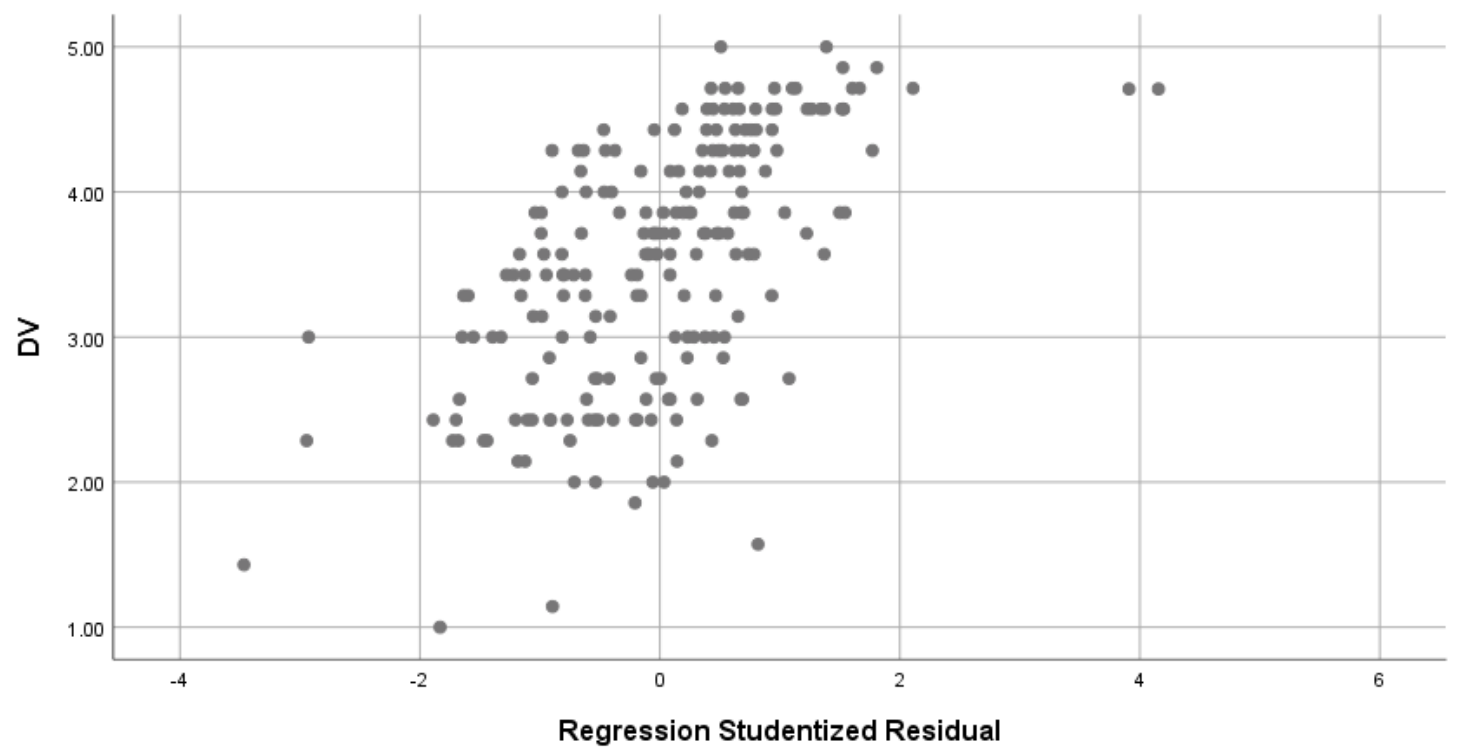

FIGURE 4.10 Scatterplot for Homoscedasticity Assumption 
The scatterplot and the histogram both indicate normal distribution which also indicates linearity of data. Fulfilling the linearity assumption of data. Thus, all four assumptions of, normality, linearity, homoscedasticity and no multicollinearity have been fulfilled.

\subsubsection{Hypotheses Testing}

Table 4.7 shows the respective beta and t values. The beta $(\beta)$ values is used to determine which independent variable has the most effect on the dependent variable (Hair et al., 2010). Vending environment $(\beta=0.288)$ is seen as having the greatest effect on the dependent variable (family succession in the food hawking business of Malaysia), followed by preparation level of heir $(\beta=0.262)$, relationship among family members $(\beta=0.256)$ and successor willingness $(\beta=0.145)$.

TABLE 4.7 Hypothesis Testing Results

\begin{tabular}{cccc}
\hline Hypothesis & $\beta$ & $\mathrm{t}$ & Result \\
\hline Vending & $0.288^{* * * *}$ & 3.586 & Supported \\
Environment & & & \\
Operating Hours & 0.048 & 0.588 & Not Supported \\
Preparation Level & $0.262^{* * *}$ & 4.066 & Supported \\
of Heir & & & \\
Relationship & $0.256^{* * *}$ & & Supported \\
Among Family & & & \\
Members & & & \\
Successor & $0.145^{* *}$ & & \\
Willingness & & & \\
\hline R2 $=0.643, \mathrm{~F}=72.913$, Sig. 0.000 & & \\
$* * * \mathrm{p}<0.001 ; * * \mathrm{p}<0.01 ; * \mathrm{p}<0.05 ; \beta=$ Standardized coefficients Beta
\end{tabular}

Therefore, the regression equation (using unstandardized $\beta$ ) is formulated as: 


$$
\begin{aligned}
\mathrm{DV}=-0.519 & +0.297(V E)+0.045(O H)+0.321(P H)+0.300(R E) \\
& +0.136(S W)
\end{aligned}
$$

The equation implies that all independent variables possess a positive relationship with the dependent variable. We can derive from the equation that the dependent variable will increase by 0.297 if vending environment increases by 1 , provided that other independent variables remain the unchanged. Consequently, if operating hours, preparation level of heir, relationship among family members and successor willingness increase by 1 , the dependent variable will increase by $0.045,0.321,0.300$ and 0.136 respectively; provided that the remaining variables remain constant. The y-intercept $(-0.519)$ indicates the mean value of the dependent variable when all independent variables equal zero.

\subsubsection{Moderator Analysis}

Table 4.8 shows the impact of the potential moderator, leader's approval on the relationships between the independent variables and the dependent variable. As seen in model 3 of the table, leader's approval was found to be not significant in the moderation of any of the relationships between the independent variables and the dependent variable.

TABLE 4.8 Impact of Leader's Approval on the Relationship between IV Dimensions and The Dependent Variable

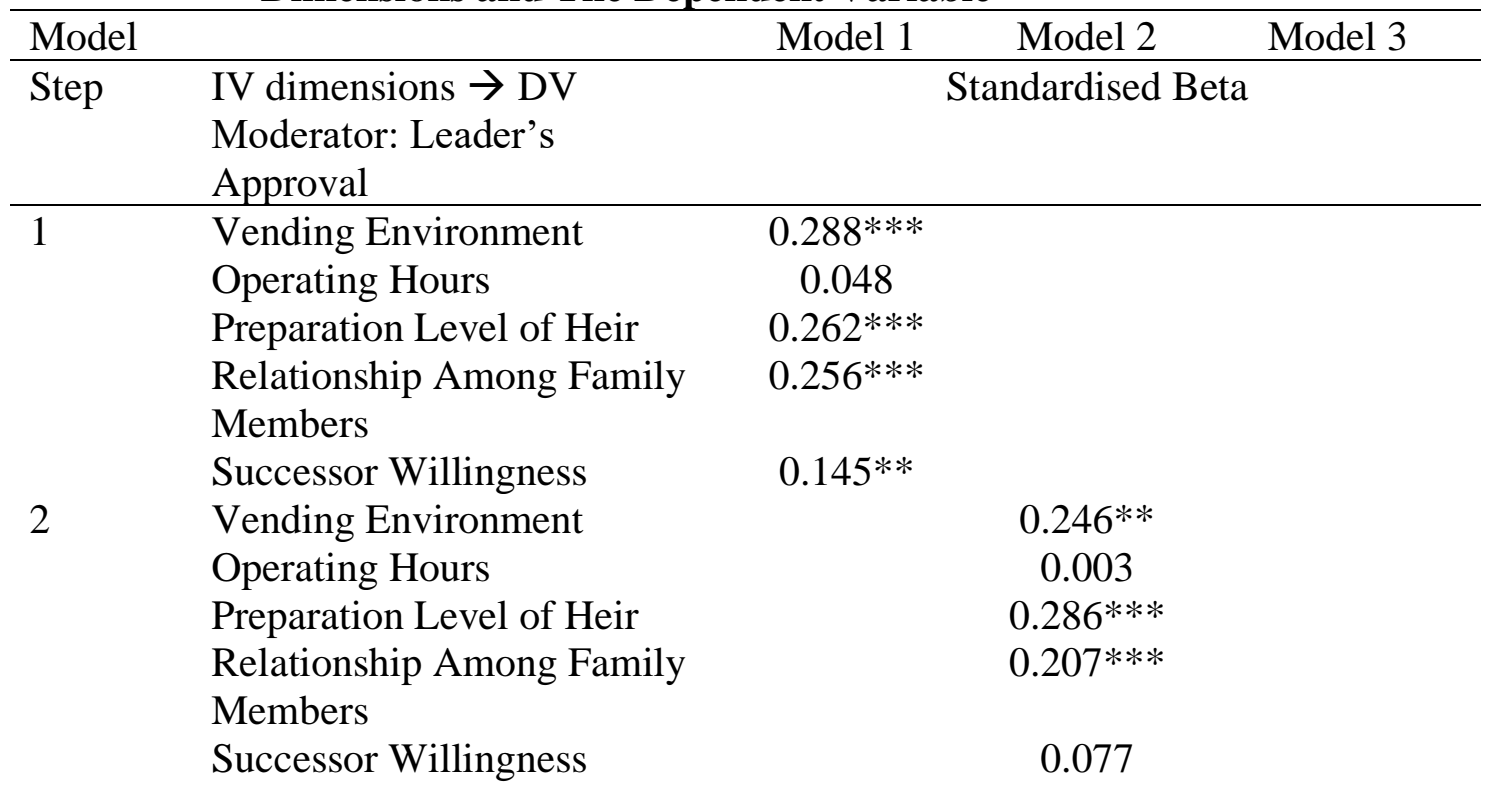




\begin{tabular}{|c|c|c|c|c|}
\hline \multirow{19}{*}{3} & Leader's Approval & \multicolumn{3}{|c|}{$0.246 * * *$} \\
\hline & Vending Environment & & & -0.208 \\
\hline & Operating Hours & & & 0.220 \\
\hline & Preparation Level of Heir & & & 0.051 \\
\hline & Relationship Among Family & & & 0.151 \\
\hline & \multicolumn{4}{|l|}{ Members } \\
\hline & Successor Willingness & & & 0.385 \\
\hline & Leader's Approval & & & -0.089 \\
\hline & Vending Environment $\mathrm{x}$ & & & 0.704 \\
\hline & \multicolumn{4}{|l|}{ Leader's Approval } \\
\hline & Operating Hours x Leader's & & & -0.286 \\
\hline & \multicolumn{4}{|l|}{ Approval } \\
\hline & Preparation Level of Heir $\mathrm{x}$ & & & 0.433 \\
\hline & \multicolumn{4}{|l|}{ Leader's Approval } \\
\hline & Relationship Among Family & & & 0.088 \\
\hline & \multicolumn{4}{|l|}{ Members x Leader's } \\
\hline & \multicolumn{4}{|l|}{ Approval } \\
\hline & \multirow{2}{*}{\multicolumn{4}{|c|}{$\begin{array}{l}\text { Successor Willingness X } \\
\text { Leader's Approval }\end{array}$}} \\
\hline & & & & \\
\hline & R Square & 0.643 & 0.689 & 0.702 \\
\hline & Adjusted R Square & 0.635 & 0.680 & 0.685 \\
\hline & F Value & $72.913 * * *$ & $74.273 * * *$ & $42.000 * * *$ \\
\hline & F Change & $72.913 * * *$ & $29.550 * * *$ & 1.706 \\
\hline & R Square Change & 0.643 & 0.046 & 0.013 \\
\hline
\end{tabular}

$* * * \mathrm{p}<0.001 ; * * \mathrm{p}<0.01 ; * \mathrm{p}<0.05$. Step 1 refers to regression with IV dimensions. Step 2 refers to regression with IV dimensions and the moderator (Leader's Approval). Step 3 refers to regression with IV dimensions, moderator and interaction terms. 


\section{DISCUSSION AND CONCLUSION}

\subsection{INTRODUCTION}

This final section will discuss the results obtained from the data analyses by discussing the results in relation to pass literature and studies, as described in the literature review. This section will also provide implications of the study, limitations, recommendations for future studies, as well as a conclusion for the study.

\subsection{DISCUSSION OF FINDINGS}

\subsubsection{Vending Environment}

The hypothesis is supported, vending environment satisfaction is significantly related to family succession in the food hawking business of Malaysia. The results agree with the reports of Kei (2015) and Kok (2018), as it was reported that young hawkers did not see the benefits of working in an unsatisfactory work environment that was both hot and cramped; this made them less likely to succeed the family hawker business. Other studies (Kuratko \& Hodgetts, 2004; Westhead, 2003) done on work environment effects on family succession were performed in a non-hawker and non-food service setting. These studies also assumed that family firms are no longer involved in management and therefore separates ownership from management. Therefore, the result can be viewed as a new and novel finding in family succession in the food hawking business of Malaysia, in comparison to these studies. 


\subsubsection{Preparation Level of Heir}

The hypothesis is supported, preparation level of heir is significantly related to family succession in the food hawking business of Malaysia. The result agrees with the reports of Lam (2007), Castillo (2006), Lorna (2010), Sardeshmukh \& Corbett (2011) and Mokhber et al., (2017). However, it is worth noting that these studies were also performed in a non-hawker and non-food service setting that assumed the separation of family from management. Therefore, the findings of preparation level of heir on the family hawker business succession can also be viewed as a new and novel finding in the family hawker business succession topic.

\subsubsection{Relationship Among Family Members}

The hypothesis is supported, relationship among family members is significantly related to family succession in the food hawking business of Malaysia. The results are in agreement with Castillo (2006), Lorna (2010), Mokhber et al., (2017), Kaunda \& Nkhoma (2013) and Helin \& Jabri (2016). These studies were performed once again in a non-hawker and non-food service setting that assume the separation of family from management; the target sample population for these studies were family successors of large family firms and not small family businesses. Hence, the findings of relationship among family members and family succession in the food hawking business of Malaysia can be seen as new and novel.

\subsubsection{Successor Willingness}

The hypothesis is supported, successor willingness is significantly related to family succession in the food hawking business of Malaysia. The result is in agreement with the findings of Tarulevicz (2018). The study of Tarulevicz (2018) is more similar to this study as it examines the likelihood of potential family successors in the food hawking business 
in Singapore; it is therefore similar in terms of the target population. The findings are aligned with the results of this study as Tarulevicz (2018) reported that if successors were willing to succeed the family hawker business, they would do so regardless of their current job and income. The results are also in agreement with Wang, Lo \& Weng (2019) that successor willingness influences the sustainability of a business through appropriate successors in a family firm; it should be noted however that this study examined large family firms as opposed to small family run businesses.

\subsubsection{Operating Hours}

The hypothesis is not supported, operating hours is not significantly related to family succession in the food hawking business of Malaysia. This factor is insignificant as compared to the reports of long working hours dissatisfaction by hawkers (Chong, 2019; Kei, 2015; Kok, 2018). Kei (2015) and Kok (2018) reported that hawkers in Singapore were not satisfied with their working hours. This difference may be due to the fact that hawkers in Malaysia may not put as much emphasise on the working hours when family succession is considered.

\subsubsection{Leader's Approval}

Leader's approval was found to be not significant as a moderator to all five hypotheses. The non-existent moderation for all the study hypothesis could be due to the fact that Wang, Lo \& Weng (2019) studied the effects of leader's approval as a moderating variable in the context of large family business firms that assume the separation of family from management. The study recruited participants who were already not involved in the management of the business, therefore, leader's approval in that study may have had a different effect towards the succession of family members in a large family firm. 


\subsection{IMPLICATIONS OF THE STUDY}

\subsubsection{Managerial Implications}

Based on the results of this study, vending environment has the largest influence on the family hawker business succession in Malaysia. As such, it is the responsibility of the Malaysian government and the city councils of respective states in Malaysia to ensure that the operating environment of hawkers is satisfactory in terms of the tools, space and maintenance. For example, the city council of Kuala Lumpur or Dewan Bandaraya Kuala Lumpur (DBKL) recognise the positive contribution of hawkers and petty traders to the economy of the county and encourages development of hawker areas and petty traders. DBKL has also devised plans to relocate hawkers to permanent building locations to improve the work environment of hawkers ("Kuala Lumpur Structure Plan 2020: Commerce", 2020).

The second most significant factor on the family hawker business succession in Malaysia found in this study is preparation level of heir. Hawker elderships should ensure that potential family successors are trained and equipped with proper professional qualities and capabilities that are associated with the hawker business. Hawker elderships may incorporate training and oversee the progress of their potential successors to achieve a better probability of family succession. The eldership should also promote interpersonal community relationships in the potential successor to improve their preparation to serve the needs of the community as customers of their business. Wang, Lo \& Weng (2015) has also concluded that preparation level of heir is significant in ensuring the sustainability of a business.

The third most significant factor found in this study is relationship among family members. Therefore, hawker owners or elderships should strive to improve their relationship with their family members, as this will ensure a higher probability of succession in their food hawking business. Hawker elderships should strive to improve their relationship with their successor as supported by Castillo (2006), Lorna (2010), 
Mokhber et al., (2017), Kaunda \& Nkhoma (2013) and Helin \& Jabri (2016). This will also help to ensure a higher probability of hawker business sustainability.

Successor willingness is the fourth most significant factor in this study and can be cultivated and improved by doing all the above; improving relationship among family members, preparation level of heir and vending environment. Doing so will increase the probability of successor willingness in the potential successor as the hawker business will become a more attractive career option. Therefore, the respective stakeholders such as the hawker elders and the government of Malaysia should prioritize these variables when taking action to ensure that time and resources can be used efficiently. This study will aid the endangered food hawking businesses in Malaysia, for a more sustainable business and economy. This study will also encourage the younger people in pursuing their family owned food hawking business.

\subsubsection{Theoretical Implications}

This study has expanded upon the theory for more in-depth studies to determine the future supply of food hawkers to ensure food hawking sustainability as suggested by Chong (2019). This study will also contribute to the scarce research on succession and the factors affecting family business succession as reported by Lucky, Minai and Isaiah (2011). As pointed out by Heck et al. (2008), it is necessary to increase the research output in the area of family business research; of which this study has also contributed to. This study will further improve the small number of family business research and help in the identification of factors affecting family business succession. This will ensure further increase comprehension of the relationship of the variables chosen. This study is also useful towards the unification of family business theory with the practical managerial applications in real life, ensuring an evidence-based approach when attempting to solve family business succession issues.

As mentioned, most family succession studies were performed on large family firms and organisations that assume the separation of family members from managerial responsibilities. This study contributes to the even smaller number of studies performed 
on small family businesses and hawker businesses; where ownership and managerial responsibilities lie with the same individual family member.

\subsection{LIMITATIONS OF THE STUDY}

Sample size insufficiency threatens the validity and generalizability of results (Vasileiou, Barnett, Thorpe, \& Young, 2018). As a result, the sample size in this study may not be sufficiently representative of the entire hawker population of Malaysia; therefore, these results must be interpreted in the appropriate context and may not be sufficiently generalisable to all hawkers in Malaysia. Non probability convenience sampling was used in this study due to time constraints; convenience sampling is subjected to sampling bias attributed to possible under-representation of subgroups in the target population (Bornstein, Jager, \& Putnick, 2013). The results thus cannot be generalised to the target population due to potential bias; the inferences made should be interpreted only about the study sample itself. The questionnaire survey methodology is also prone to response bias, where respondents respond inaccurately or falsely to questions which may negatively affect the validity of the questionnaire surveys (Furnham, 1986). Although steps have been taken to ensure the reliability and validity of the questionnaire, irritated respondents may resort to untruthful answers which may influence the outcomes of the study.

\subsection{RECOMMENDATIONS FOR FUTURE RESEARCH}

Due to time constraints, a cross sectional approach was used to perform this study. It is recommended that future studies in this area consider a longitudinal approach. This is to enable analysis of these variables over a prolonged period of time (Shadish, Cook, \& Campbell, (2002). It is also recommended that researchers increase the sample size to improve questionnaire validity and generalisation of results over the target population (Vasileiou, Barnett, Thorpe, \& Young, 2018). The conceptual framework should either be revised or expanded upon by including additional variables of interest in order to test the relationship of these new variables to the dependent variable. The qualitative 
interview methodology may also be used to obtain more detailed personal information, allow more detailed questions to be asked and to clarify ambiguity that can arise with questionnaire surveys (Weiss, 1995).

\subsection{CONCLUSION}

In conclusion, four out of five study variables (vending environment, preparation level of heir, relationship among family members and successor willingness) were found to be significant in the successful family succession in the food hawking business in Malaysia. The level of significance in ascending order are successor willingness, vending environment, preparation level of heir and relationship among family members. Operating hours was found to be not significantly related, possibly due to the differences in importance and consideration by Malaysian Hawkers in family hawker succession. Leader's approval as a moderator was found to be not significant in the research model, this may be due to potential family successors not putting weightage on or being indifferent to the approval of the eldership in the context of a hawker business. Additional empirical studies are required to test the relationships in different settings and further validate the results.

\subsection{CONFLICT OF INTEREST DECLARATION}

The author declares no conflict of interest in preparing this article. 


\section{REFERENCES}

Afshar Jahanshahi, A., Nawaser, K., \& Brem, A. (2018). Corporate entrepreneurship strategy: an analysis of top management teams in SMEs. Baltic Journal of Management, 13(4), 528-543. doi: 10.1108/bjm-12-2017-0397

Au, K. (2018). Editorial for the special section: transgenerational entrepreneurship in the global world. Cross Cultural \& Strategic Management, 25(4), 546-549. doi: 10.1108/ccsm-10-2018-219

Badawy, T. A. E., Alaadin, Y., \& Magdy, M. M. (2016). Succession planning, job engagement and job satisfaction: the missing link. Middle East J. of Management, 3(1). doi: 10.1504/mejm.2016.077108

Bakotić, D., \& Babić, T. (2013). Relationship between Working Conditions and Job Satisfaction: The Case of Croatian Shipbuilding Company. International Journal of Business and Social Science, 4(2). Retrieved from https://www.researchgate.net/publication/303854477_Relationship_between_working_c onditions_and_job_satisfaction_The_case_of_Croatian_shipbuilding_company

Barney, J. (1991). Firm Resources and Sustained Competitive Advantage. Journal Of Management, 17(1), 99-120. doi: 10.1177/014920639101700108

Basco, R., Calabrò, A., \& Campopiano, G. (2018). Transgenerational entrepreneurship around the world: Implications for family business research and practice. Journal of Family Business Strategy. doi: 10.1016/j.jfbs.2018.03.004

Best food streets in KL: Jalan Alor. (2014). Retrieved 26 February 2020, from https://www.timeout.com/kuala-lumpur/food-and-drink/best-food-streets-in-kl-jalanalor

Boateng, G., Neilands, T., Frongillo, E., Melgar-Quiñonez, H., \& Young, S. (2018). Best Practices for Developing and Validating Scales for Health, Social, and Behavioral Research: A Primer. Frontiers In Public Health, 6. doi: 10.3389/fpubh.2018.00149

Bornstein, M. H., Jager, J., \& Putnick, D. L. (2013). Sampling in developmental science: Situations, shortcomings, solutions, and standards. Developmental Review, 33(4), 357370. doi: 10.1016/j.dr.2013.08.003

Bush, A. (2015). George Town's street food: what to eat in Malaysia's food capital Lonely Planet. $\quad$ Retrieved March 2019, from https://www.lonelyplanet.com/articles/george-towns-top-10-dishes-what-to-order-insoutheast-asias-food-capital

Castillo J., \& Wakefield (2006). An exploration of firm performance factors in family business: do family value only the "bottom line"?. Journal of Small Business Strategy, 17(1), 37-51. 
Chen, E., \& Nowland, J. (2010). Optimal Board Monitoring in Family-owned Companies: Evidence from Asia. Corporate Governance: An International Review, 18(1), 3-17. doi: 10.1111/j.1467-8683.2009.00778.x

Chong, N. (2019). Making Food Hawking in Penang Sustainable [Ebook] (pp. 1-10). Penang: Penang Institute. Retrieved from https://penanginstitute.org/publications/issues/making-food-hawking-in-penangsustainable/

Chrisman, J. J., Chua, J. H., Le Breton-Miller, I., Miller, D., \& Steier, L. P. (2018). Governance Mechanisms and Family Firms. Entrepreneurship Theory and Practice, 42(2), 171-186. https://doi.org/10.1177/1042258717748650

Coffman, B. (2014). The Family Business Succession Model: An Exploratory Analysis Of Factors Impacting Family Business Succession Preparedness. Ph.D. Kansas State University.

Collins, L. (2010). To succeed or not to succeed: A multiple perspectives literature review of research in family business succession. International Family Enterprise Research Acedemy. Retrieved from https://www.researchgate.net/publication/277844297_To_succeed_or_not_to_succeed A_multiple_perspectives_literature_review_of_research_in_family_business_successio $\underline{\mathrm{n}}$

Connelly, L. (2008). Pilot studies. Medsurg Nursing, 17(6), 411-412.

Dowler, E., Bauer, M., Green, J., \& Gasperoni, G. (2006). Assessing public perception: issues and methods. In C, Dora (Ed.). Health, Hazard and Public Debate: Lessons for Risk Communication From the Bse/Cjd Saga. (1st ed., pp. 40-60). Retrieved from https://www.researchgate.net/publication/30528118_Assessing_public_perception_issu es_and_methods

Eisenhardt, K. (1989). Agency Theory: An Assessment and Review. The Academy Of Management Review, 14(1), 57. doi: 10.2307/258191

Furnham, A. (1986). Response bias, social desirability and dissimulation. Personality and Individual Differences, 7(3), 385-400. doi: 10.1016/0191-8869(86)90014-0

George Boole | British mathematician. (2019). Retrieved 4 December 2019, from https://www.britannica.com/biography/George-Boole

Gunzler, D., \& Morris, N. (2015). A tutorial on structural equation modeling for analysis of overlapping symptoms in co-occurring conditions usingMPlus. Statistics In Medicine, 34(24), 3246-3280. doi: 10.1002/sim.6541

Hair, J. F., Black, W. C., Babin, B. J., \& Anderson, R. E. (2010). Multivariate data analysis (7th ed.). Upper Saddle River, New Jersey: Pearson.

Hall, D. (1986). Dilemmas in linking succession planning to individual executive learning. Human Resource Management, 25(2), 235-265. doi: 10.1002/hrm.3930250206 
Hampel-Milagrosa, A., Loewe, M., \& Reeg, C. (2015). The Entrepreneur Makes a Difference: Evidence on MSE Upgrading Factors from Egypt, India, and the Philippines. World Development, 66, 118-130. doi: 10.1016/j.worlddev.2014.08.005

Heck, R., Hoy, F., Poutziouris, P., \& Steier, L. (2008). Emerging Paths of Family Entrepreneurship Research. Journal Of Small Business Management, 46(3), 317-330. doi: 10.1111/j.1540-627x.2008.00246.x

Helin, J., \& Jabri, M. (2016). Family business succession in dialogue: The case of differing backgrounds and views. International Small Business Journal: Researching Entrepreneurship, 34(4), 487-505. doi: 10.1177/0266242614567482

Henderson, J., Yun, O., Poon, P., \& Biwei, X. (2012). Hawker centres as tourist attractions: The case of Singapore. International Journal of Hospitality Management, 31(3), 849-855. doi: 10.1016/j.ijhm.2011.10.002

Hinkin, T. (1995). A Review of Scale Development Practices in the Study of Organizations. Journal Of Management, 21(5), 967-988. doi: $10.1177 / 014920639502100509$

Hoffman, J., Hoelscher, M., \& Sorenson, R. (2006). Achieving Sustained Competitive Advantage: A Family Capital Theory. Family Business Review, 19(2), 135-145. doi: 10.1111/j.1741-6248.2006.00065.x

Iyenda, G. (2001). Street food and income generation for poor households in Kinshasa. Environment And Urbanization, 13(2), 233-241. doi: $10.1177 / 095624780101300218$

Jager, J., Putnick, D., \& Bornstein, M. (2017). II. MORE THAN JUST CONVENIENT: THE SCIENTIFIC MERITS OF HOMOGENEOUS CONVENIENCE SAMPLES. Monographs Of The Society For Research In Child Development, 82(2), 1330. doi: 10.1111/mono.12296

Kaunda, S., \& Nkhoma, A. (2013). Intergenerational survival of family businesses: factors affecting the succession success of family owned businesses in Malawi. European Journal Of Business And Management, 5(7).

Kei, Y. (2015). Young Singaporean Hawkers - We Speak To The Unsung Heroes of Our Food Culture. Retrieved 26 November 2019, from https://thesmartlocal.com/read/younghawkers-interview/

Kirchherr, J., \& Charles, K. (2018). Enhancing the sample diversity of snowball samples: Recommendations from a research project on anti-dam movements in Southeast Asia. PLOS ONE, 13(8), e0201710. doi: 10.1371/journal.pone.0201710

Kline, R. (2011). Principles and practice of structural equation modeling (3rd ed.). New York: Guilford Press.

Kline, R. (2015). Principles and practice of structural equation modeling (4th ed.). New York: Guilford Press. 
Kok, X.H. (2018, Dec 18). If Singapore's food hawkers are so good, why pay them so little?. Retrieved from https://www.scmp.com/week-asia/lifestyleculture/article/2178363/if-singapores-unesco-food-hawkers-are-so-good-why-pay

Kuala Lumpur Structure Plan 2020 : Commerce. (2020). Retrieved 15 March 2020, from http://www.dbkl.gov.my/psk12020/english/commerce/index.htm\#7_2_6

Kuratko, D., \& Hodgetts, R. (2004). Entrepreneurship: Theory, Process, and Practice 6TH EDITION (6th ed.). Mason, Ohio: Thomson/South-Western.

Lam, J. (2009). Succession process in a large Canadian family business : a longitudinal case study of the Molson family business : 1786-2007. Family Business Review, 1(2). Retrieved from https://www.semanticscholar.org/paper/Succession-process-in-a-largeCanadian-family-\%3A-a-\%3A-Lam/eb33b28dbc28fe9d1b62530a98febe8784b05e6f

Lane, K. A., Esser, J., Holte, B., \& Mccusker, M. A. (2010). A study of nurse faculty job satisfaction in community colleges in Florida. Teaching and Learning in Nursing, 5(1), 16-26. doi: 10.1016/j.teln.2009.05.001

Le Breton-Miller, I., \& Miller, D. (2009). Agency vs. Stewardship in Public Family Firms: A Social Embeddedness Reconciliation. Entrepreneurship Theory And Practice, 33(6), 1169-1191. doi: 10.1111/j.1540-6520.2009.00339.x

Lepold, A., Tanzer, N., Bregenzer, A., \& Jiménez, P. (2018). The Efficient Measurement of Job Satisfaction: Facet-Items versus Facet Scales. International Journal of Environmental Research And Public Health, 15(7), 1362. doi: 10.3390/ijerph15071362

Lorna, C. (2011). Implications for family-owned business successions: A multiple perspectives review and suggestions for further research. Retrieved from https://www.semanticscholar.org/paper/IMPLICATIONS-FOR-FAMILY-OWNEDBUSINESS-SUCCESSIONS\%3A/89ebabcc11fa47b19fc782ce3f3556b345e09a55

Lucky, E.O., Minai, M.S., M., \& Isaiah, A.O. (2011). A Conceptual Framework of Family Business Succession: Bane of Family Business Continuity. International Journal of Business And Social Science, 2(18). 106-113

MacKinnon, D. (2011). Integrating Mediators and Moderators in Research Design. Research On Social Work Practice,21(6), 675-681. doi: $10.1177 / 1049731511414148$

Miller, D., Steier, L., \& Le Breton-Miller, I. (2003). Lost in time: intergenerational succession, change, and failure in family business. Journal Of Business Venturing, 18(4), 513-531. doi: 10.1016/s0883-9026(03)00058-2

Mokhber, M., Tan, G., Abdul Rasid, S., Vakilbashi, A., Mohd Zamil, N., \& Yee, W. (2017). Succession planning and family business performance in SMEs. Journal of Management Development, 36(3). 
Morris, M., Williams, R., \& Nel, D. (1996). Factors influencing family business succession. International Journal Of Entrepreneurial Behavior \& Research, 2(3), 68-81. doi: $10.1108 / 13552559610153261$

Muzaffar, A., Huq, I., \& Mallik, B. (2009). Entrepreneurs of the Streets: an Analytical Work on the Street Food Vendors of Dhaka City. International Journal Of Business And Management, 4(2). doi: 10.5539/ijbm.v4n2p80

New Straits Time. (2016). Penang endorsed as world's best food destination by renowned food writer. [online] Available at: https://www.nst.com.my/news/2016/07/158992/penang-endorsed-worlds-best-fooddestination-renowned-food-writer [Accessed 30 Jan. 2020].

Pearson, A., \& Marler, L. (2010). A Leadership Perspective of Reciprocal Stewardship in Family Firms. Entrepreneurship Theory And Practice, 34(6), 1117-1124. doi: 10.1111/j.1540-6520.2010.00416.x

Perret, S. (2016). Succession in Family Owned Businesses: The Influence of Succession Planning and Demographic Characteristics on Succession Success. Ph.D. Louisiana State University.

Perri, A., \& Peruffo, E. (2017). Family Business and Technological Innovation (1st ed., pp. 9-40). Palgrave Macmillan.

Pritchett, R., Kemp, J., Wilson, P., Minnis, H., Bryce, G., \& Gillberg, C. (2010). Quick, simple measures of family relationships for use in clinical practice and research. A systematic review. Family Practice, 28(2), 172-187. doi: 10.1093/fampra/cmq080

Raziq, A., \& Maulabakhsh, R. (2015). Impact of Working Environment on Job Satisfaction. Procedia Economics And Finance, 23, 717-725. doi: 10.1016/s22125671(15)00524-9

Raziq, A., \& Maulabakhsh, R. (2015). Impact of Working Environment on Job Satisfaction. Procedia Economics and Finance, 23, 717-725. doi: 10.1016/s22125671(15)00524-9

Republic of Singapore Department of Statistics, Ministry of Trade and Industry. (2017). Average Weekly Paid Hours Worked Per Employee by Industry. In Republic of Singapore Department of Statistics, Ministry of Trade and Industry (Ed.). Yearbook of Statistics Singapore 2017. (1st ed., pp.317-320. Retrieved from https://www.singstat.gov.sg//media/files/publications/reference/yearbook_2017/yos2017.pdf

Rhoton, C. (2014). A MULTIPLE REGRESSION AND CONCURRENT VALIDITY ANALYSIS OF HIGH SCHOOL SENIORS' SOCIAL COMPETENCE, ABILITY TO MANAGE EMOTIONS, AND THEIR TIME SPENT ON FACEBOOK (Doctor of Education). Liberty University.

Ruel, M., Haddad, L., \& Garrett, J. (1999). Some Urban Facts of Life: Implications for Research and Policy. World Development, 27(11), 1917-1938. doi: 10.1016/s0305750x(99)00095-9 
Sardeshmukh, S., \& Corbett, A. (2011). The Duality of Internal and External Development of Successors: Opportunity Recognition in Family Firms. Family Business Review, 24(2), 111-125. doi: 10.1177/0894486510391783

Saunders, M., Lewis, P., \& Thornhill, A. (2012). Research methods for business students (6th ed.). Harlow, United Kingdom: Pearson Education Limited.

Shadish, W. R., Cook, T. D., \& Campbell, D. T. (2002). Experimental and quasiexperimental designs for generalized causal inference (2nd ed.). Boston, Massachusetts: Wadsworth Cengage Learning.

Sim, F. (2018). NEA suggests changes to contract terms between social enterprises, hawkers. $\quad$ Retrieved $26 \quad$ November 2019 , from https://www.channelnewsasia.com/news/singapore/social-enterprise-hawker-centresnea-contracts-10912672

Taber, K. (2017). The Use of Cronbach's Alpha When Developing and Reporting Research Instruments in Science Education. Research In Science Education, 48(6), 1273 1296. doi: 10.1007/s11165-016-9602-2

Tan, D. (2017). Higher tourist arrivals in Penang. Retrieved 8 December 2019, from https://www.thestar.com.my/business/business-news/2017/12/11/higher-tourist-arrivalsin-penang

Tarulevicz, N. (2018). Hawkerpreneurs: Hawkers, Entrepreneurship, and Reinventing Street Food in Singapore. Revista De Administração De Empresas, 58(3), 291-302. doi: 10.1590/s0034-759020180309

Tsang, S., Royse, C., \& Terkawi, A. (2017). Guidelines for developing, translating, and validating a questionnaire in perioperative and pain medicine. Saudi Journal of Anaesthesia, 11(5), 80. doi: 10.4103/sja.sja_203_17

Walsh, G., Beatty, S., \& Shiu, E. (2009). The customer-based corporate reputation scale: Replication and short form. Journal Of Business Research, 62(10), 924-930. doi: 10.1016/j.jbusres.2007.11.018

Vasileiou, K., Barnett, J., Thorpe, S., \& Young, T. (2018). Characterising and justifying sample size sufficiency in interview-based studies: systematic analysis of qualitative health research over a 15-year period. BMC Medical Research Methodology, 18(1). doi: 10.1186/s12874-018-0594-7

Wang, Y., Lo, F., \& Weng, S. (2019). Family businesses successors knowledge and willingness on sustainable innovation: The moderating role of leader's approval. Journal Of Innovation \& Knowledge, 4(3), 188-195. doi: 10.1016/j.jik.2019.05.001

Wang, Y., Lo, F., \& Weng, S. (2019). Family businesses successors knowledge and willingness on sustainable innovation: The moderating role of leader's approval. Journal Of Innovation \& Knowledge , 4(3), 188-195. doi: 10.1016/j.jik.2019.05.001 
Weiss, R. S. (1995). Learning from strangers: the art and method of qualitative interview studies. New York: Free Press.

Westhead, P. (2003). Succession Decision-Making Outcomes Reported by Private Family Companies. International Small Business Journal: Researching Entrepreneurship, 21(4), 369-401. doi: 10.1177/02662426030214001

Whisman, M., \& McClelland, G. (2005). Designing, Testing, and Interpreting Interactions and Moderator Effects in Family Research. Journal Of Family Psychology, 19(1), 111-120. doi: 10.1037/0893-3200.19.1.111

Whitehead, A., Julious, S., Cooper, C., \& Campbell, M. (2015). Estimating the sample size for a pilot randomised trial to minimise the overall trial sample size for the external pilot and main trial for a continuous outcome variable. Statistical Methods In Medical Research, 25(3), 1057-1073. doi: 10.1177/0962280215588241

World Health Organization. (1996). Essential safety requirements for street-vended foods [Ebook]. Retrieved from https://www.who.int/foodsafety/publications/streetvended-food/en/

Zellweger, T., Nason, R., \& Nordqvist, M. (2011). From Longevity of Firms to Transgenerational Entrepreneurship of Families. Family Business Review, 25(2), 136155. doi: $10.1177 / 0894486511423531$

Zur, A., \& Walega, A. (2015). Routines do matter: role of internal communication in firm-level entrepreneurship. Baltic Journal Of Management, 10(1), 119-139. doi: 10.1108/bjm-11-2013-0166 
APPENDIX A

Variables and Measurements for Questionnaire

Variables

Measurements

Reference scale

\begin{tabular}{|c|c|c|c|}
\hline Vending & VE1 & I am satisfied with the working & $\begin{array}{l}\text { (Lepold, Tanzer, } \\
\text { Breoenzer \& }\end{array}$ \\
\hline & VE2 & $\begin{array}{l}\text { I am satisfied with the working } \\
\text { tools and materials. }\end{array}$ & $\begin{array}{l}\text { Jiménez, 2018) } \\
\text { (Raziq \& }\end{array}$ \\
\hline & VE3 & $\begin{array}{l}\text { I am satisfied with the current } \\
\text { maintenance of the premises. }\end{array}$ & $\begin{array}{l}\text { Maulabakhsh, } \\
\text { 2015) }\end{array}$ \\
\hline & VE4 & $\begin{array}{l}\text { There is sufficient space at your } \\
\text { workplace. }\end{array}$ & \\
\hline $\begin{array}{l}\text { Operating } \\
\text { Hours }\end{array}$ & $\mathrm{OH} 1$ & $\begin{array}{l}\text { I am satisfied with the working } \\
\text { hours. }\end{array}$ & $\begin{array}{l}\text { (Lepold, Tanzer, } \\
\text { Bregenzer \& }\end{array}$ \\
\hline & $\mathrm{OH} 2$ & $\begin{array}{l}\text { I am satisfied with the consideration } \\
\text { of my wishes in organizing my } \\
\text { working hours. }\end{array}$ & Jiménez, 2018) \\
\hline & $\mathrm{OH} 3$ & $\begin{array}{l}\text { I am satisfied with the organization } \\
\text { of break times. }\end{array}$ & \\
\hline & OE4 & $\begin{array}{l}\text { I am satisfied with the } \\
\text { holidays/vacation times. }\end{array}$ & \\
\hline $\begin{array}{l}\text { Preparation } \\
\text { Level of Heir }\end{array}$ & PH1 & $\begin{array}{l}\text { The successor should be equipped } \\
\text { with professional qualities and } \\
\text { capabilities. }\end{array}$ & $\begin{array}{l}\text { (Hampel- } \\
\text { Milagrosa, } \\
\text { Loewe \& Reeg, }\end{array}$ \\
\hline & $\mathrm{PH} 2$ & $\begin{array}{l}\text { The successor should have crisis } \\
\text { awareness and response capability. }\end{array}$ & $\begin{array}{l}\text { 2015) } \\
\text { (Wang, Lo \& }\end{array}$ \\
\hline & PH3 & $\begin{array}{l}\text { The successor should have talent } \\
\text { development and utilization } \\
\text { capability. }\end{array}$ & Weng, 2019) \\
\hline & PH4 & $\begin{array}{l}\text { The successor should have } \\
\text { interpersonal community } \\
\text { relationships. }\end{array}$ & \\
\hline & PH5 & $\begin{array}{l}\text { The successor plans to expand the } \\
\text { hawker business scope. }\end{array}$ & \\
\hline & PH6 & $\begin{array}{l}\text { The successor generally prefers } \\
\text { challenging work. }\end{array}$ & \\
\hline $\begin{array}{l}\text { Relationship } \\
\text { among Family } \\
\text { Members }\end{array}$ & RM1 & $\begin{array}{l}\text { I am satisfied with the help that I } \\
\text { receive from my family when } \\
\text { something is troubling me. }\end{array}$ & $\begin{array}{l}\text { (Pritchett et al., } \\
\text { 2010) }\end{array}$ \\
\hline & RM2 & $\begin{array}{l}\text { I am satisfied with the way my } \\
\text { family discusses items of common } \\
\text { interest and shares problem solving } \\
\text { with me. }\end{array}$ & \\
\hline
\end{tabular}




\section{Successor willingness}

Leader's approval

Intention of Family succession in the
RM3 I find that my family accepts my wishes to take on new activities or make changes in my life-style.

RM4 I am satisfied with the way my family expresses affection and responds to my feelings such as anger, sorrow, and love.

RM5 I am satisfied with the amount of time my family and I spend together.

SW1 The successor wants to control the business in all aspects.

(Wang, Lo \&

Weng, 2019)

SW2 The successor wants to make the family business more prosperous.

SW3 The successor will input most of their personal time in the business.

SW4 The successor wants to be approved by the eldership.

SW5 The successor will give up a job he/she loves for succession of the family hawker business.

SW6 The successor will enjoy higher flexibility when working in the family business.

LA1 The family business will face greater difficulties in operation

(Walsh, Beatty \& Shiu, 2009) after the retirement of the eldership. (Wang, Lo \&

LA2 The leadership is quite willing to Weng, 2019) delegate power.

LA3 The leadership lost his/her passion for work.

LA4 The leadership intends to retire soon.

LA5 The leadership will not trust anyone other than family members, and will not delegate his/her powers to non-family to handle the affairs of the family business.

FS1 Family member(s) have defined (Coffman, 2014) roles within the business. 
food hawking FS2 Effective communication among

business in

family members exists within the

Malaysia

business.

FS3 The successor is ready to step in if unexpectedly required.

FS4 There is an active development plan for the next generation successor.

FS5 The ownership succession plan includes a time frame.

FS6 A successor has been chosen.

FS7 The successor has been made aware of the owner's decision. 


\section{Appendix B}

TABLE 4.1 Demographic Information of Respondents

\begin{tabular}{|c|c|c|c|}
\hline Variables & Category & Frequency & Percentage (\%) \\
\hline \multirow[t]{2}{*}{ Gender } & Female & 97 & 46.6 \\
\hline & Male & 111 & 53.3 \\
\hline \multirow[t]{5}{*}{ Age } & 25 years or less & 42 & 20.2 \\
\hline & 26 to 30 years & 24 & 11.5 \\
\hline & 31 to 40 years & 62 & 29.8 \\
\hline & 41 to 45 years & 39 & 18.8 \\
\hline & Above 45 years & 41 & 19.7 \\
\hline \multirow[t]{4}{*}{ Race } & Chinese & 143 & 68.8 \\
\hline & Indian & 22 & 10.6 \\
\hline & Malay & 41 & 19.7 \\
\hline & Others & 2 & 1.0 \\
\hline \multirow{6}{*}{$\begin{array}{l}\text { Education } \\
\text { Level }\end{array}$} & Less than & 2 & 1.0 \\
\hline & primary & & \\
\hline & Primary & 27 & 13.0 \\
\hline & Secondary & 146 & 70.2 \\
\hline & Diploma & 6 & 2.9 \\
\hline & $\begin{array}{l}\text { Bachelor's } \\
\text { degree }\end{array}$ & 27 & 13.0 \\
\hline \multirow{9}{*}{$\begin{array}{l}\text { Total Monthly } \\
\text { Household } \\
\text { Income }\end{array}$} & Below RM2500 & 49 & 23.6 \\
\hline & RM2500 to & 116 & 55.8 \\
\hline & RM6500 & & \\
\hline & RM6500 to & 21 & 10.1 \\
\hline & RM10500 & & \\
\hline & RM10500 to & 18 & 8.7 \\
\hline & RM14500 & & \\
\hline & RM14500 to & 4 & 1.9 \\
\hline & RM18500 & & \\
\hline \multirow[t]{2}{*}{ State Residing } & Kuala Lumpur & 31 & 14.9 \\
\hline & Penang & 177 & 85.1 \\
\hline \multirow[t]{3}{*}{ Marital Status } & Married & 134 & 64.4 \\
\hline & Single & 69 & 33.2 \\
\hline & Divorced & 5 & 2.4 \\
\hline
\end{tabular}


TABLE 4.2 Central Tendencies of Constructs Summary

\begin{tabular}{|c|c|c|c|}
\hline Variables & Items & Mean & $\begin{array}{l}\text { Standard } \\
\text { Deviation }\end{array}$ \\
\hline Vending & VE 1 & 3.49 & 0.973 \\
\hline \multirow[t]{3}{*}{ Environment (VE) } & VE 2 & 3.52 & 0.937 \\
\hline & VE 3 & 3.39 & 0.910 \\
\hline & VE 4 & 3.39 & 0.895 \\
\hline \multirow{4}{*}{$\begin{array}{l}\text { Operating Hours } \\
\qquad(\mathrm{OH})\end{array}$} & $\mathrm{OH} 1$ & 3.56 & 1.048 \\
\hline & $\mathrm{OH} 2$ & 3.61 & 1.011 \\
\hline & $\mathrm{OH} 3$ & 3.47 & 0.997 \\
\hline & $\mathrm{OH} 4$ & 3.30 & 0.992 \\
\hline \multirow{6}{*}{$\begin{array}{c}\text { Preparation Level of } \\
\text { Heir }(\mathrm{PH})\end{array}$} & PH 1 & 3.61 & 0.844 \\
\hline & PH 2 & 3.62 & 0.843 \\
\hline & PH 3 & 3.50 & 0.799 \\
\hline & $\mathrm{PH} 4$ & 3.72 & 0.895 \\
\hline & PH 5 & 3.62 & 0.865 \\
\hline & PH 6 & 3.62 & 0.825 \\
\hline \multirow{5}{*}{$\begin{array}{c}\text { Relationship Among } \\
\text { Family Members } \\
\text { (RE) }\end{array}$} & RE 1 & 4.00 & 0.814 \\
\hline & RE 2 & 4.03 & 0.892 \\
\hline & RE 3 & 3.92 & 0.903 \\
\hline & RE 4 & 3.95 & 0.872 \\
\hline & RE 5 & 3.94 & 0.869 \\
\hline & SW 1 & 3.62 & 1.005 \\
\hline \multirow{5}{*}{ Willingness (SE) } & SW 2 & 3.77 & 1.038 \\
\hline & SW 3 & 3.73 & 1.047 \\
\hline & SW 4 & 3.61 & 1.015 \\
\hline & SW 5 & 3.71 & 1.042 \\
\hline & SW 6 & 3.73 & 0.991 \\
\hline \multirow{5}{*}{$\begin{array}{c}\text { Leader's Approval } \\
\text { (LA) }\end{array}$} & LA 1 & 3.47 & 0.873 \\
\hline & LA 2 & 3.70 & 0.958 \\
\hline & LA 3 & 3.48 & 0.937 \\
\hline & LA 4 & 3.56 & 0.961 \\
\hline & LA 5 & 3.43 & 1.000 \\
\hline \multirow{7}{*}{$\begin{array}{l}\text { Intention of Family } \\
\text { Succession in the } \\
\text { Food Hawking } \\
\text { Business in Malaysia } \\
\text { (DV) }\end{array}$} & DV 1 & 3.49 & 0.948 \\
\hline & DV 2 & 3.57 & 0.981 \\
\hline & DV 3 & 3.56 & 0.936 \\
\hline & DV 4 & 3.47 & 0.932 \\
\hline & DV 5 & 3.51 & 0.938 \\
\hline & DV 6 & 3.48 & 1.116 \\
\hline & DV 7 & 3.52 & 1.090 \\
\hline
\end{tabular}


Table 4.3 Cronbach's Alpha Values of Sample Data

\begin{tabular}{lc}
\hline \multicolumn{1}{c}{ Variables } & Cronbach's Alpha Value \\
\hline Vending Environment (VE) & 0.915 \\
Operating Hours (OH) & 0.921 \\
Preparation Level of Heir (PH) & 0.907 \\
Relationship Among Family Members & 0.896 \\
(RE) & \\
Successor Willingness (SW) & 0.947 \\
Leader's Approval (LA) & 0.901 \\
Intention of Family Succession in the & 0.942 \\
Food Hawking Business in Malaysia & \\
(DV) & \\
\hline
\end{tabular}

TABLE 4.4 Skewness and Kurtosis Summary

\begin{tabular}{|c|c|c|c|}
\hline Variables & Items & Skewness & Kurtosis \\
\hline Vending environment & VE 1 & -.213 & -.456 \\
\hline \multirow[t]{3}{*}{$(\mathrm{VE})$} & VE 2 & -.266 & -.379 \\
\hline & VE 3 & -.075 & -.520 \\
\hline & VE 4 & -.046 & -.614 \\
\hline \multirow[t]{4}{*}{ Operating hours $(\mathrm{OH})$} & $\mathrm{OH} 1$ & -.180 & -.956 \\
\hline & $\mathrm{OH} 2$ & -.206 & -.805 \\
\hline & OH 3 & -.069 & -.695 \\
\hline & $\mathrm{OH} 4$ & -.058 & -.608 \\
\hline Preparation level of heir & PH 1 & -.328 & -.447 \\
\hline \multirow[t]{5}{*}{$(\mathrm{OH})$} & PH 2 & -.457 & .350 \\
\hline & PH 3 & -.345 & .148 \\
\hline & PH 4 & -.318 & -.601 \\
\hline & PH 5 & -.218 & -.361 \\
\hline & PH 6 & -.458 & -.031 \\
\hline Relationship among & RE 1 & -.589 & -.004 \\
\hline \multirow[t]{4}{*}{ Family Members (RE) } & RE 2 & -.726 & -.139 \\
\hline & RE 3 & -.444 & -.625 \\
\hline & RE 4 & -.480 & -.268 \\
\hline & RE 5 & -.414 & -.568 \\
\hline Successor willingness & SW 1 & -.263 & -.875 \\
\hline$(\mathrm{SW})$ & SW 2 & -.441 & -.845 \\
\hline
\end{tabular}




\begin{tabular}{llll} 
& SW 3 & -.411 & -.900 \\
& SW 4 & -.248 & -.692 \\
Leader's approval (LA) & SW & -.330 & -.950 \\
& SW 6 & -.358 & -.758 \\
& LA 1 & -.006 & -.469 \\
LA 2 & -.259 & -.715 \\
Intention of Family & LA 3 & .088 & -.862 \\
Succession in the Food & LA 4 & -.034 & -.805 \\
Hawking Business in & LA 5 & -.047 & -.724 \\
Malaysia (DV) & DV 1 & -.161 & -.612 \\
& DV 2 & -.283 & -.547 \\
& DV 3 & -.365 & -.162 \\
& DV 4 & -.132 & -.398 \\
& DV 5 & -.188 & -.553 \\
& DV 6 & -.193 & -.907 \\
\hline
\end{tabular}

TABLE 4.5 Model summary

\begin{tabular}{llll}
\hline Model & R Square & F & Sig. \\
\hline 1 & .643 & 72.913 & $.000 * * *$ \\
\hline$* * * \mathrm{p}<0.001$ & & &
\end{tabular}

TABLE 4.6 Multicollinearity Test

\begin{tabular}{lccc}
\hline Variables & Tolerance & VIF & Condition Index \\
\hline Vending Environment & .274 & 3.646 & 11.506 \\
Operating Hours & .268 & 3.726 & 14.005 \\
Preparation Level of & .426 & 2.350 & 18.896 \\
Heir & & & \\
Relationship Among & .754 & 1.327 & 21.807 \\
Family Members & & & \\
Successor & .624 & 1.604 & 24.731 \\
Willingness & & & \\
\hline
\end{tabular}




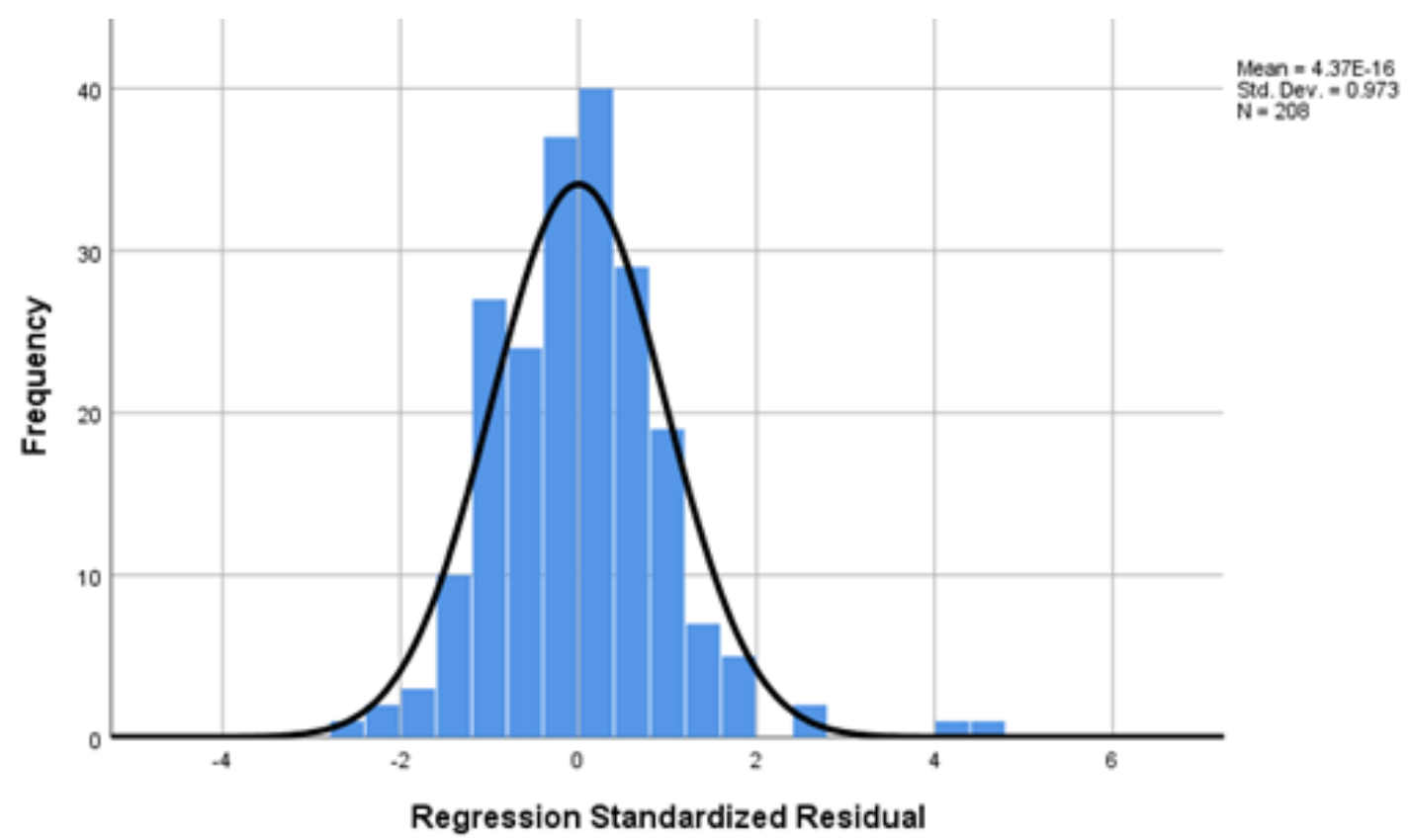

FIGURE 4.8 Histogram for Normality Assumption

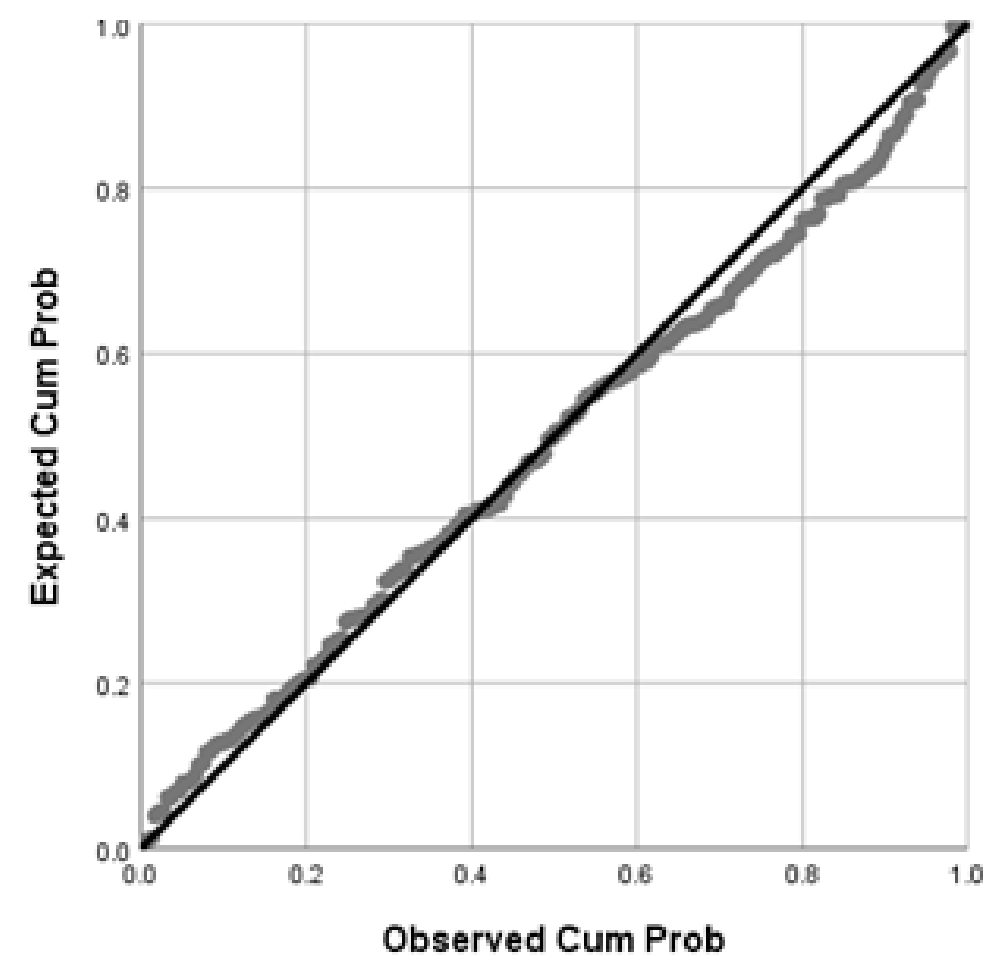

FIGURE 4.9 P-P Plot of Regression Studentised Residual 


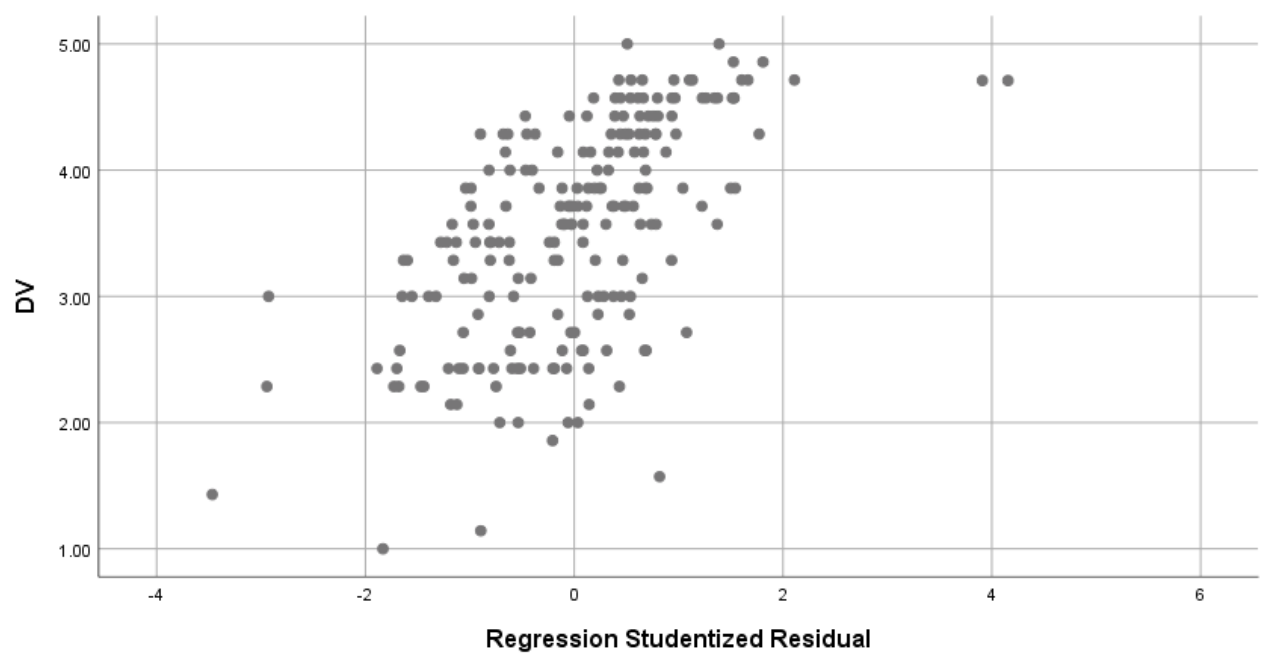

FIGURE 4.10 Scatterplot for Homoscedasticity Assumption

TABLE 4.7 Hypothesis Testing Results

\begin{tabular}{cccc}
\hline Hypothesis & $\beta$ & $\mathrm{t}$ & Result \\
\hline Vending & $0.288^{* * *}$ & 3.586 & Supported \\
Environment & & & \\
Operating Hours & 0.048 & 0.588 & Not Supported \\
Preparation Level & $0.262^{* * *}$ & 4.066 & Supported \\
of Heir & & & Supported \\
Relationship & $0.256^{* * *}$ & 5.297 & Supported \\
Among Family & & & \\
Members & & 2.720 & \\
Successor & $0.145^{* *}$ & & \\
Willingness & & &
\end{tabular}

$\mathrm{R} 2=0.643, \mathrm{~F}=72.913$, Sig. 0.000

$* * * p<0.001 ; * * p<0.01 ; * p<0.05 ; \beta=$ Standardized coefficients Beta 
TABLE 4.8 Impact of Leader's Approval on the Relationship between IV Dimensions and The Dependent Variable

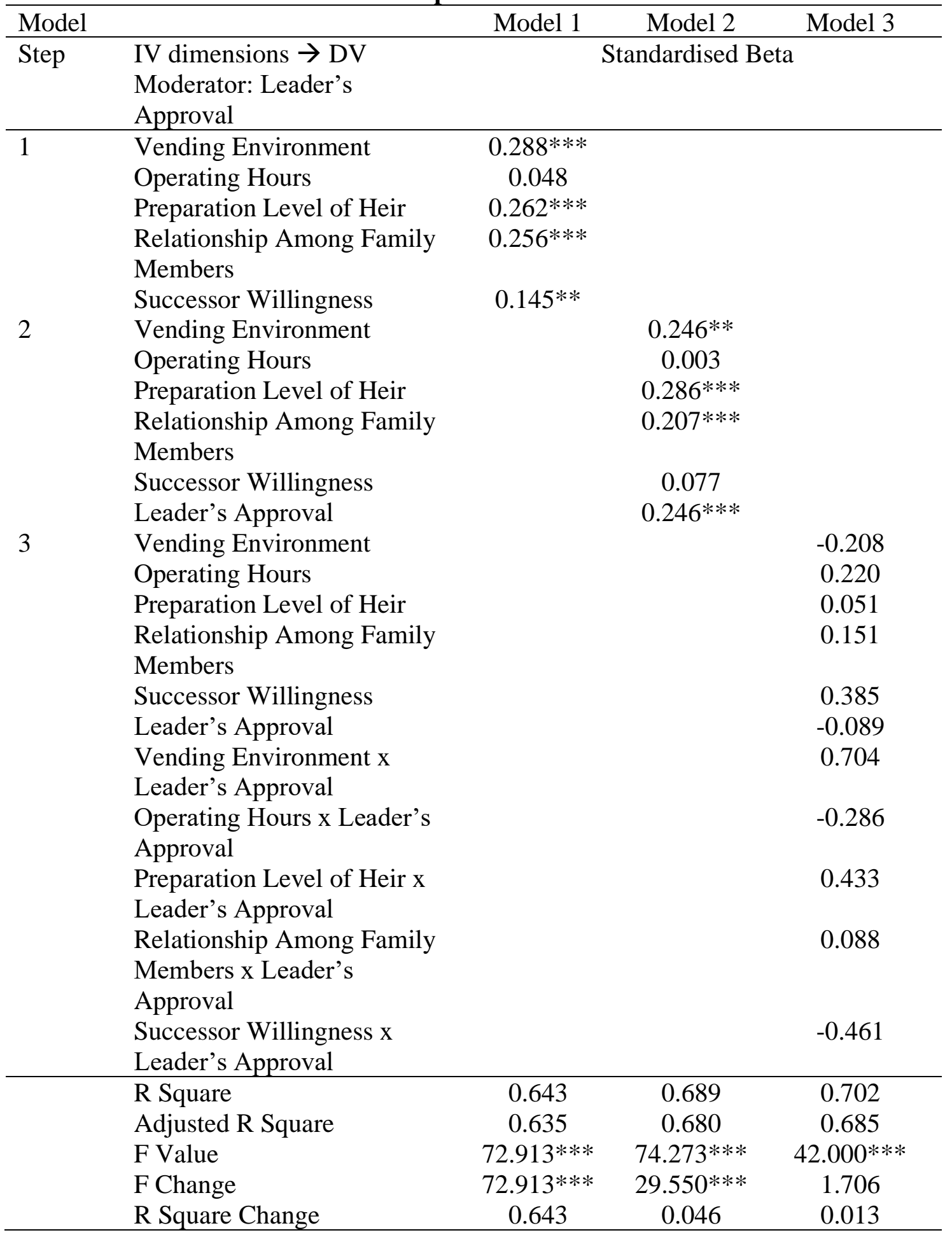

$* * * \mathrm{p}<0.001 ; * * \mathrm{p}<0.01 ; * \mathrm{p}<0.05$. Step 1 refers to regression with IV dimensions. Step 2 refers to regression with IV dimensions and the moderator (Leader's Approval). Step 3 refers to regression with IV dimensions, moderator and interaction terms. 


\section{Appendix C}

\section{UCSI UNIVERSITY \\ Factors Affecting Family Business Succession in the Food Hawking Business in Malaysia}

\section{Survey Questionnaire}

Dear Respondent,

My name is Jonathan $\mathrm{Ng}$ Cho Kin, I am a postgraduate student of Master of Business Administration at UCSI university. The purpose of this survey is to conduct a research to investigate the factors affecting family business succession in the food hawking business in Malaysia. Please answer all questions honestly. There are no right or wrong answers to any of these questions. All responses are collected for the sole purpose of academic research and will be kept strictly confidential.

Thank you for your participation.

\section{Instructions:}

1) There are EIGHT (8) sections in this questionnaire. Please answer ALL questions in ALL sections.

2) Completion of this form should take you no more than 10 minutes.

3) The contents of this questionnaire will be kept strictly confidential.

\section{Voluntary Nature of the Study}

Participation in this research is entirely voluntary. Even if you decide to participate now, you may change your mind and stop at any time. There is no foreseeable risk of harm or discomfort in answering this questionnaire. This questionnaire survey is anonymous; as such, tracing responses back to any individual participant is not possible. All information collected will be treated confidential for the sole purpose of this study.

I have been informed about the purpose of the study and I readily give my consent to participate in this study.

YES ( ) NO ( )

Note: If yes, please proceed to the first section. If no, you exit the webpage. Thank you for your time and cooperation. 


\section{LIST OF ABBREVIATIONS AND SYMBOLS}

B

$\beta \quad$ Beta

C

CCSM Cross Cultural \& Strategic Managemen

D

DBKL Dewan Bandaraya Kuala Lumpur

DV Dependent Variable

$\mathbf{E}$

ETP Entrepreneurship Theory and Policy

I

IV Independent Variable

$\mathbf{L}$

LA Leader's Approval

M

M Moderator

MLR Multiple Linear Regression

O

$\mathrm{OH} \quad$ Operating Hours

$\mathbf{P}$

PH Preparation level of Heir

$\mathbf{R}$

RBV Resource-based Framework

RE Relationship among Family Members

$\mathbf{S}$

Sig Significant

SME Small and Medium-sized Enterprises

SPSS Statistical Products and Service Solutions

STEP Successful Transgenerational Entrepreneurship Practices

SW Successor Willingness

V

VE Vending Environment 
$\mathbf{X}$

$\mathrm{X}$ Independent Variable Value

Y

Y Dependent Variable Value 